\title{
Studies of indigenous lithic procurement in Uruguay and their implications for Southern Cone archaeology
}

\author{
Nicolás Batalla \\ Museu de Arqueologia e Etnologia, Universidade de São Paulo, São Paulo, SP, Brazil. \\ Email: arnico.batalla@gmail.com
}

\begin{abstract}
:
Being a territory with several minerals and rocks suitable for knapping and grinding, Uruguay offered a lithic-rich environment for past indigenous cultures in the Southern Cone of South America. In this paper, a history of lithic procurement studies in Uruguay is presented. Three main periods are discriminated, paying attention to authors' theoretical and methodological contributions to the field. Firstly, a period with general mention to raw materials utilised by indigenous groups, including those historically known, is recognised at least since the last decades of the nineteenth century. Secondly, a period involving description of lithic resources available at a national scale as well as the first detailed observations of lithic sources and possible means of procurement can be distinguished between the 1950s and the mid-1980s. Lastly, beginning with salvage archaeology in the eastern region, the current period of research (i.e. the last thirty years) is characterised by contextualising lithic procurement within issues of lithic technological organisation and settlement patterns of indigenous groups. The current period of studies has involved two different approaches: 1) technological analysis of lithic artefacts and comparison of raw material with previously-published geological data; 2) utilisation of field survey data that locate and map lithic resources, and characterisation of visual (macroscopic, microscopic, or both macroscopic and microscopic) and geochemical components of these resources. Within the latter, studies can be further arranged according to the main temporal framework used to contextualise research problems. On the one hand, questions involving lithic procurement of early hunter-gatherers (who arrived $c a$. 12,000 BP) since the end of the 1990s have included surveys of potential and utilised sources, the first thin-section-based petrographic studies and the distinction of different local, regional and long-distance procurement strategies. On the other hand, cultural changes since the Middle Holocene have framed lithic source survey studies to answer questions of resource accessibility for coastal groups during sea level changes, as well as for other now-diverse groups such as the lowland moundbuilders. Finally, considerations for future research are made by reconsidering recent developments alongside the history of lithic procurement studies in Uruguay.
\end{abstract}

Keywords: lithic procurement; Uruguay; research frameworks; Southern Cone archaeology; indigenous lithic technology

Published by the School of History, Classics and Archaeology, University of Edinburgh ISSN: 2055-0472. URL: http://journals.ed.ac.uk/lithicstudies/

This work is licensed under a Creative Commons Attribution 2.5 UK: Scotland License. 


\section{Introduction}

Lithic procurement studies are concerned with processes and products involving the acquisition of minerals and rocks, linking survey, analysis and characterisation of sources with raw material use and circulation (Church 1994; Luedkte 1992; Odell 2000; 2004). The Uruguayan territory, in the South America Southern Cone (see Figures 1 and 2), offers a unique environment for these studies, since it was a very rich and diverse lithic landscape for indigenous artisans, for knapping and grinding. This is in contrast with others areas of the Southern Cone such as the Pampean region where lithic resources are highly localised (e.g., Bayón et al. 1999; Colombo 2013; Flegenheimer \& Bayón 1999), although there do exist other regions with abundant and widely distributed resources, such as Patagonia (e.g., Borrero \& Franco 1997; Magnin 2015).

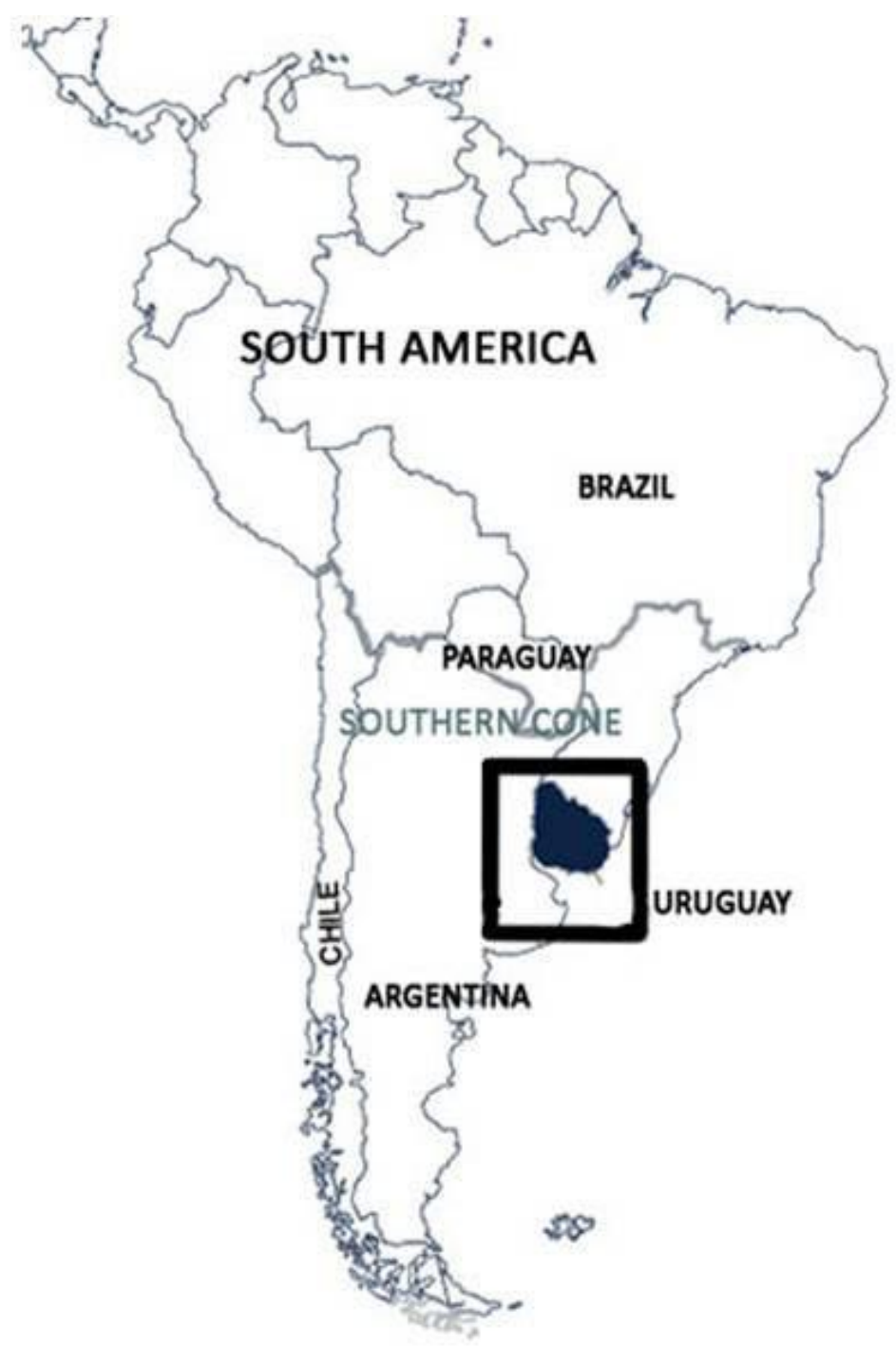

Figure 1. The location of the study area within South America

The aim of this article is to present a history of lithic procurement studies in Uruguay. It is an attempt to bring together the references on the topic to a wider audience, since the majority of them are published in Spanish (for a similar review of Argentina see Colombo 2013: 55-99; for Brazil, see Penha 2015: 23-24). The emphasis of this review is on major theoretical and methodological developments and, although a brief mention of main resources utilized by indigenous societies is given, a specific description of each is not intended. 


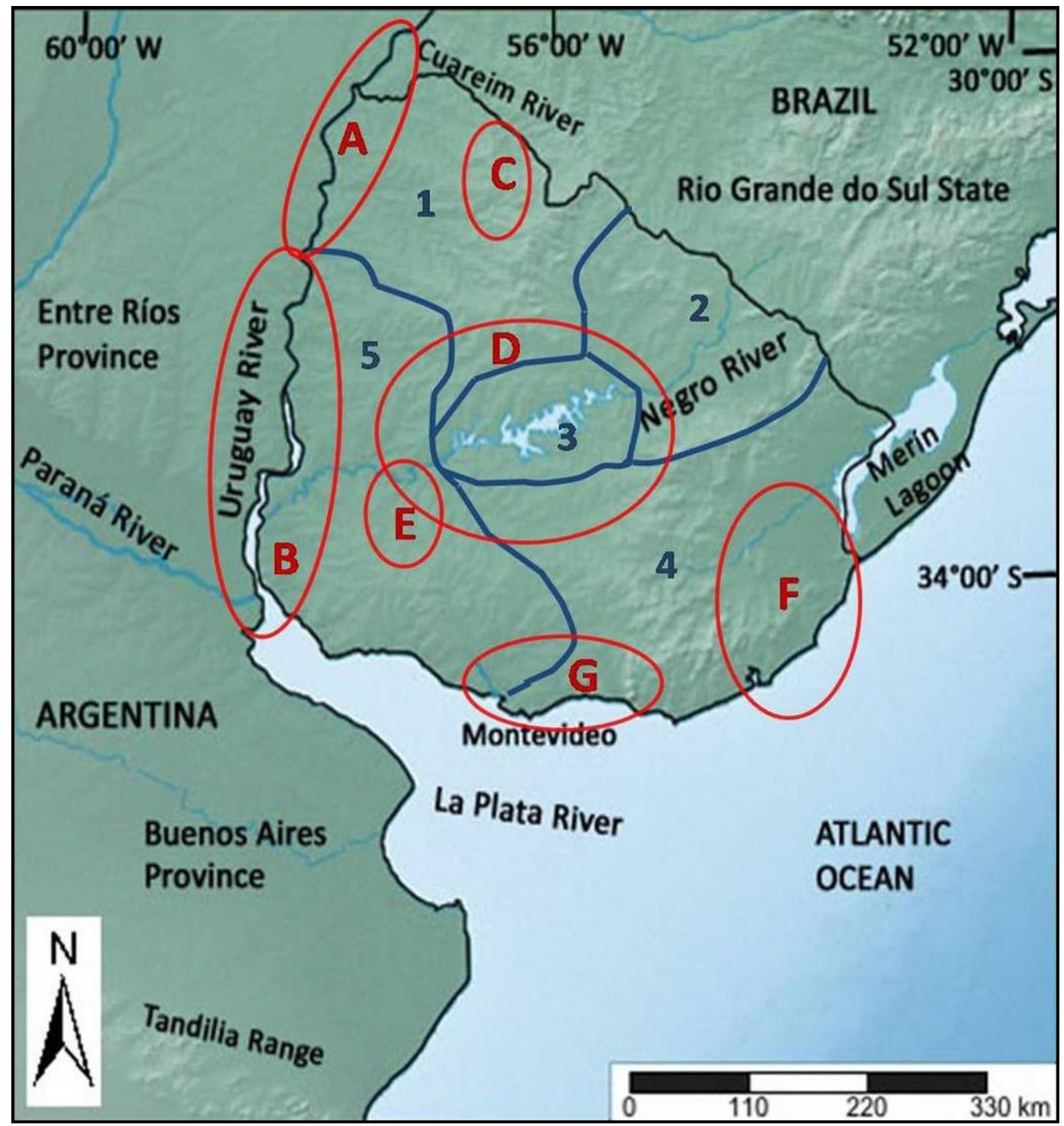

Figure 2. Lithic procurement study regions in Uruguay. Lines and numbers indicate areas with dominant knapping and grinding-suitable materials, as reported by and modified from Baeza (1992: 12-13): 1. North, silicified limestone, chalcedony, agate and basalt; 2 . Northeast, silicified wood, silicified limestone, granite and effusive rocks; 3. Central (Middle Negro River), silicified limestone, chalcedony and basalt; 4. South and southeast, vein quartz, chalcedony, granitic, effusive (e.g., rhyolitic) and metamorphic rocks; 5. West, silicified limestone, basalt and granitic rocks. Circles and letters indicate main study regions: A. Middle Uruguay River and Cuareim River; B. Lower Uruguay River; C. Catalanes-Arapey (including Catalán Chico River sites) archaeological region (Suárez 2010; 2011b); D. Central area (Tacuarembó River, Middle Negro River and Yaguarí creek sites); E. Grande creek and tributaries (Gascue 2009; 2013); F. Southeast and Atlantic coast; G. South, including Santa Lucía River basin and eastern La Plata River coast.

Instead of a strict chronological sequence of publications, the article is arranged thematically, considering distinct major challenges and the archaeological and geological approaches used to address them. A critical review is made that emphasises authors' contributions regarding: Analysis of primary and secondary sources (based on Luedtke 1979) 
and their character (potential vs. utilised (quarries and extraction sites)); localisation, knapping quality, and other source characteristics (dimensions and morphology); on-source provisioning techniques, including collection, extraction and quarrying (Haury 1995); and raw material use concerns, through artefact reduction sequence, mobility and exchange analysis (Andrefsky 2009). Finally, a consideration of major developments is made in order to propose new lines of future research.

\section{First descriptions}

In the 1870s, the Argentinean pioneer of archaeology and Earth sciences in the La Plata River region, Florentino Ameghino, made a field trip to Uruguay, in the context of (among others) his interest in 'Quaternary Man' and the association between extinct mammals and human artefacts (Ameghino 1877; 1918; for his observations on Uruguayan Pleistocene occupations see Suárez 2011a). In that work, Ameghino made both specific observations of the country's geology and general descriptions of lithic raw materials utilised by indigenous peoples to manufacture different knapped and ground artefacts. Among the raw materials suitable for knapping, Ameghino (1877: 9) included quartz, quartzite, agate and chalcedony; and for grinding, he mentioned granite and diorite. The diversity of minerals and rocks with which Indians in southern Uruguay made their artefacts, as well as the distances from which these materials could have been transported, amazed him (Ameghino 1918: 214-216). He also noticed the presence of artefacts made from obsidian (see also Baeza 2013) and made an interesting observation about its procurement: “... piedra que seguramente deben haberla traído de mui lejos" ('a stone they must have brought from far away') (Ameghino 1877: 9). In the Argentinean Pampean region, Ameghino was the first to hypothesize about different lithic resources and various ways of obtaining them among the early inhabitants (e.g., Ameghino 1918; Bayón et al. 1999).

Almost fifteen years later, José H. Figueira (1892; also 1900a; 1900b; 1900c) made observations about lithic raw materials and published photographs about lithic artefacts found in various surface sites (paraderos in the terminology of that time) around the country. The aim of those descriptions was to introduce the 'primitive' cultures from the young country of Uruguay to an educated European audience, during an exposition in commemoration of the Spanish conquest of America (Curbelo 2004). With respect to lithic procurement, Figueira (1892: 161; 1900c: 564) continued with Ameghino's reasoning regarding the possibility of prehistoric long distance transport, but without specifying the types of rock obtained in such manner. In particular, he made the first mention of a supposed indigenous quarry in Uruguay, from where he collected some cores: "Los grandes núcleos de sílex provienen de un taller situado en el Pedernal, que es donde se halla el yacimiento de sílex más importante que conozco en el país" ('The big chert cores are from a workshop in the Pedernal, where is located the most important chert quarry that I know of') (Figueira 1892: 218).

A particular interest on the topic of lithic procurement was not developed in the first half of the twentieth century. Archaeology in Uruguay was then a quest for indigenous artefacts that were interpreted literally in light of what European chroniclers had written about ethnic groups encountered in the La Plata River basin since the sixteenth century (e.g., Charrúa, Chaná) (Curbelo 2004: 266). During this period, some observations were made by members of an elite institution made up of amateur archaeologists. The so-called 'Society of Friends of Archaeology' (Sociedad Amigos de la Arqueología), founded in 1926, was devoted to the divulgation and conservation of antiquities, including fossils, public buildings and prehistoric artefacts. Among their observations was the use of local siliceous resources for manufacturing two lithic "Charrúan" fish hooks found on the eastern coast (Demaría 1932: 196) and mention to raw materials utilised for knapping and grinding artefacts (e.g., "exceptional" projectile 
points, see Sollazo \& Seijo (1932), and sculptural polished artefacts, see Sierra y Sierra (1931); for raw materials used for these and other exceptional knapped and ground artefacts, see Meneghin $(2004 ; 2006 ; 2007 ; 2011)$. The latter were common in other references of the time (e.g., Geranio 1939; Maeso 1977), and a particular reference to the incomparable availability of rocks that the country offered to "Charrúa" indigenous groups was made by Maeso (1977: 34), a poet and amateur archaeologist who traveled around the country for more than forty years collecting and digging up artefacts (Tuya de Maeso 1977).

\section{The first lithic resource lists and source descriptions}

The first description of available resources for knapping and grinding at a national scale was made by the geographer, biologist and botanist Jorge Chebataroff. In a work published by an amateur archaeologist in the fifties (Maruca Sosa 1957; see also Chebataroff 1955), Chebataroff recognised the diversity of high quality rocks and minerals for manufacturing tools, and classified them in line with the most up-to-date geological knowledge of the country at that time. The general pattern he identified (in Maruca Sosa 1957: 245-246), although since updated (e.g., Baeza 1992), remains valid until today (see Figure 2): Silicified sandstones, chalcedony and agates in the northern region; silicified limestone whose reddish variety is locally known as carneolita, and chalcedony in the western and central region; quartz and amphibolites in the south; and quartzite and siliceous rocks in the eastern region, which he highlighted as a rich are for suitable grinding rocks as well (e.g., basalt).

Chebataroff also reflected on the importance of quarry studies, raising the possibility that rock would have not always been locally procured: “... es necesario que se haga una investigación acerca de los yacimientos de roca o mineral utilizado (...) A veces el material trabajado se encontraba en yacimientos inmediatos a los talleres o paraderos; pero existen ejemplos de que dicho material era aportado desde distancias relativamente apreciables." ('...research about utilised rock or mineral outcrops is mandatory (...) sometimes, worked material was found in outcrops next to workshops or sites; but there are examples of transfer over considerable distances') (in Maruca Sosa 1957: 247). In fact, he collaborated with several Uruguayan pioneer archaeologists studying outcrops and identifying possible sources. Among them was one of the most important precursors of professional archaeology in the country: Antonio Taddei.

In the 1960s, archaeology in Uruguay began to turn into a more academic and scientifically-informed practice as compared to the previous focus on antiquarianism, artefact collecting and description (Curbelo 2004: 270). One of the main reasons for that change was the work of Taddei (1964) in the archaeological sites of the Catalán Chico River area, in the northern region (see Figure 2, C). Discovered by Taddei in 1955, these sites were essentially composed of extensive lithic surface assemblages, mostly made up of unifacially and marginally retouched flakes (but see Hilbert 1991: 11; Suárez \& Piñeiro 2002) manufactured in locally available silicified sandstone (arenisca silicificada) (Bórmida 1964; Chebataroff 1962; Taddei 1964; Taddei \& Fernández 1982). Based on typological arrangement of the artefacts, the Catalanense industry was defined, and stratigraphical observations and subsequent comparisons with known early industries from South America (ca. 10,000 BP) posited these sites within the major problem of the peopling of the Americas (Chebataroff 1962; Taddei 1980a;1980b; 1987). For a complete analysis on this issue, see Suárez (2010).

With the geological advice of Chebataroff, Taddei (1964) made observations about silicified sandstone outcrop formation and the different ways in which the resource was available for prehistoric knappers, considering clast size and morphology. Taddei (1964: 323) noticed the availability of extensive dikes as well as clasts of different sizes, “...desde el tamaño de un puño, al de pesadas lajas de hasta $1,5 \mathrm{~cm}$ de espesor, o constituir a veces 
voluminosos bloques de más de una tonelada de peso" ("...ranging from the size of a fist to heavy $1.5 \mathrm{~cm}$ thick slabs, and even to voluminous one ton boulders").

The experience gained in the Catalán Chico sites led Taddei to consider factors influencing procurement strategies in subsequent publications. That was the case in his research in the central area of the country, at the surface sites located in the Middle Negro River and Tacuarembó Grande and Chico River basins (see Figure 2, D), a very rich archaeological region with diagnostic artefacts ranging from the early hunter-gatherer settlers of the country (e.g., Baeza et al. 2001; Bosch et al. 1980; Castiñeira et al. 2011; Gascue et al. 2013; Nami 2007; 2013; see discussion below) to Guaraní groups (Baeza \& Bosch 1975) that arrived to the Río Negro River mouth around four hundred years before the European conquest period (sixteenth century) (Castillo 2004). Based on the observed high frequencies of cortex in the artefacts collected, as well as on the abundance and accessibility of river cobbles, Taddei proposed (1980b: 26-27; see also Hilbert 1991: 17) that in that central area the raw material was always local: Silicified limestone in the western subarea and silicified sandstone in the eastern-northeastern one (Taddei 1980b; 1987). These studies (see also for this region, Baeza 1984) were important antecedents for the analysis of secondary stream sources (Luedtke 1979). A knapping industry of locally-procured basalt was also reported in this region in the seventies (Rodríguez Saccone 1973).

Brief mentions of what are today known as primary sources (Luedtke 1979) were made in different locations of the country before the eighties. Along with mention to raw materials used for artefacts collected by him, Cordero (1960: 322) reported the importance of Cerro Verde, a rocky hill in the Atlantic coast (Rocha Department), as a quarry for granite and sandstone exploited in nearby prehistoric sites. At the Cerro de los Burros locality, situated on top of a hill on the eastern La Plata coast and known at least since the fifties, Ugo Meneghin $(1970 ; 1977)$ reported the exploitation of the in situ outcropping rhyolite, which has further been recognized as a primary source with different knapping quality values (Nami 2001: 3-4). Excavations at the locality have yielded some of the earliest dates for human occupations in the country (e.g., Meneghin 2015; see also Suárez 2014; Suárez in press).

In the 1970s, the construction of an international dam across the Middle Uruguay River in the Salto Grande area (see Figure 2, A), implied several salvage surveys and excavations by different institutions. This region, together with the Argentinean northeast, was previously known for (among others) the presence of diverse ceramic types (see review in Capdepont 2013). As a result of these interventions, the first radiocarbon ages were reported for the country (Baeza 1985; CEA 1977). National pioneer archaeologists working in the area had observed several potential raw materials in the first geological profiles analysed (Melgar et al. 1975). An international rescue mission funded by different organisations in the mid-seventies (Guidon 1987), developed a geological and geomorphological study of the Middle Uruguay basin (Pellerin 1987). Archeological data suggested the use of river cobbles and slab-shaped clasts and boulders for knapping (Houot 1987: 149-150), while brief observations of potential resource areas were also made in Mesozoic-age deposits belonging to the magmaticsedimentary Paraná basin, a basin that extends across southeastern South America (Pellerin 1987: 35). Within these potential resource areas, Pellerin reported silicified sandstone for knapping (already reported for Catalán Chico assemblages) and basalt for ground artefacts, e.g. the piedras grabadas, portable engraved stones dated ca. 4,600 BP (Femenías 1985). The use of several raw materials during different periods was also noticed by archaeologists while working in this international mission (e.g., Guidon 1989; Hilbert 1991).

Apart from these generalised and opportunistic observations of available lithic raw materials, a particular interest in systematically locating and characterising sources and their regional importance was not developed until the 1980s. One of the main reasons for this was a theoretical focus on the typologies of lithic scatters as cultural or ethnic markers (Cabrera 
Pérez 2004: 187), since specific sites were perceived as products of the whole range of activities performed by discrete cultural groups. In that scheme, Catalán Chico River sites were interpreted as the expression of 'inferior hunters' (cazadores inferiores) with a 'simple' and 'monotonous' industry composed by retouched flakes, while the Middle Negro River region was thought of as the result of 'superior hunters' (cazadores superiores), with higher frequency and diversity of retouched tools and the presence of stemmed projectile points (e.g., Pi Hugarte 1993; Taddei 1980a; 1980b; 1987). Since the 1980s was an important turning point in the study of lithic procurement in Uruguay, the remainder of this article is dedicated to these most recent developments.

\section{Current research: Regional studies and frameworks for procurement analysis}

In the mid-1980s, new theoretical and methodological perspectives were incorporated into Uruguayan prehistoric archaeology, in the context of an extensive salvage survey program developed in the Merín Lagoon basin in the eastern and southeastern part of the country (see Figure 2, F). This region is of high archaeological importance in the South American lowlands for the presence of the so-called 'cerritos de indios', earthen mounds constructed between $c a$. 5,000 BP and the colonial period (Bracco et al. 2000; Iriarte et al. 2004; López Mazz 2001).

Among the questions raised by the Merín Lagoon survey researchers, Carmen Curbelo and Elianne Martínez (1992: 126; also Martínez \& Curbelo 1994), were how lithic resources were acquired, modified into artefacts, used, maintained and discarded, thus introducing into Uruguayan lithic studies the life history framework proposed by Schiffer (1972). Lithic artefacts were now to be understood in technological terms, from the point of view of strategies made by hunter-gatherers in order to cope with environmental conditions (at that moment influenced by, among others, the work of Binford (1979) and Jochim (1979), see Curbelo and Martínez (1992: 125, 153)). A technological framework for lithic studies (e.g., Andrefsky 2009; Nelson 1991) had been fully incorporated into La Plata River archaeology by the end of the eighties (Bayón \& Flegenheimer 2003: 70).

Work conducted by Curbelo \& Martínez (1992) aimed to determine hunter-gatherers' regional territorial organisation in the San Miguel hills area by studying factors affecting lithic procurement, namely, knapping quality, abundance and distance from two mound sites (CH1E01 and CH2D01). This article was the first to use an explicit lithic procurement studies framework, which employed the "lithic production systems" of Ericson (1984) by subdividing different subsystems for each raw material (e.g., quartz subsystem, rhyolite and other extrusive rocks subsystem, etc.), an approach that still influences current studies (e.g., Beovide et al. 2010; Gascue et al. 2009). The importance of Curbelo \& Martínez's work for current procurement studies lies in three main aspects: 1) It incorporated the theoretical notion that lithic production can only be understood through the different activities and places it involved, with raw material sources being of crucial significance in that organisational scheme; 2) It introduced a methodology aimed at localising potential sources with the aid of geological maps and systematic surveys, developed conjointly with geologists; 3) It considered and recorded factors or dimensions influencing procurement strategies, and standardised their different attribute states (e.g., abundance: minimum $=<10 \%$; medium $=20$ $30 \%$; maximum $=>50 \%$ ). These data for the San Miguel Hills area were later augmented by Cabrera Pérez (1995).

Since the raw material source survey of the Merín Lagoon basin, regional procurement studies in Uruguay have fallen within two main groups: 1) Technological analysis of lithic artefacts and comparison of the raw material with previously-published geological data; 2) Utilisation of field survey data that locate and map specific lithic resources, and 
characterisation of visual (macroscopic, microscopic, or both macroscopic and microscopic) (after Odell 2004: 28) and geochemical components of these resources. Both groups of studies have followed a regional scheme of the country (see Figure 2) according to main research projects: The Middle and Lower Uruguay River, the southeastern region (Atlantic coast), the southern region (including Montevideo coast and eastern La Plata River coast), the northern and northwest region, the central region (which includes the Middle Negro River) and the Santa Lucía River basin. Here, the main developments and implications of these studies are analysed, along with a brief mention of raw material characteristics they describe.

The first group of studies deals with procurement issues within the major topic of reduction sequence analysis, without developing source localisation and characterisation. During the nineties, a re-analysis was made of lithic artefacts collected during the Salto Grande archaeological rescue program (Beovide \& Caporale 2001; Cabrera Pérez 1994). Through systematising this data, Cabrera Pérez (1994: 42) suggested procurement was oriented towards different resources in different periods (e.g., siliceous during the early component, ca. 12,000-7,000 BP), a point later criticised because of the absence of supplementary data (Consens 2001) and source surveys in the study region (Suárez 2004). Other studies discussed the role played by these materials in past procurement strategies and emphasised the almost exclusive use of river cobbles in the Middle Uruguay River sites (Beovide \& Caporale 2001; but see Suárez 2011b).

A combination of available geological and archaeological information and artefactual data allowed lithic exploitation patterns for several parts of the country to be inferred (e.g., Batalla 2013; Blasco et al. 2011; Lemos \& Duarte 2013; Vega \& Andrade 2004). Unifacial implement retouch measures and indices (e.g., Kuhn (1990)'s GIUR) were calculated for Middle Negro River surface site collections made by Taddei in order to discriminate resource use (Batalla 2013). Different reduction intensities (as measured by, e.g., resharpening scars, bifacial flakes, exhausted cores) of exotic or extra-local $(>100 \mathrm{~km})$ siliceous blanks, as compared to local-regional $(15-25 \mathrm{~km})$ resources (e.g., quartz and granite), suggested variable mobility and transport strategies for groups inhabiting inland and Atlantic coastal sites (Iriarte 2000; López Mazz et al. 2009). The role of good-quality siliceous resources in eastern sites (already noticed by Curbelo \& Martínez (1992)) was later to be discriminated for different periods at Rincón de los Indios (López Mazz et al. 2009), a multicomponent site ranging from a pre-mound ( $c a .8,500 \mathrm{BP}$ ) to a ceramic mound (ca. 1,500-500 BP) component. A decrease in the use of siliceous materials towards late mound components allowed López Mazz et al. (2009) to infer a reduction in mobility range among moundbuilders (see also Iriarte \& Marozzi 2009), a proposition that, combined with other lines of evidence, has been related to more permanent settlements and social intensification since the Middle Holocene (Iriarte et al. 2004; López Mazz 2001) (see the discussion below).

The second group of procurement studies can be traced back to the general map of knappable and grindable lithologies in Uruguay presented by Jorge Baeza (1992), a work that has its roots in the observations made by Chebataroff more than thirty years before. Using geological maps and general observations on archaeological sites and lithic sources, Baeza (1992: 13) (see a modified version in Figure 2) distinguished five areas for indigenous procurement: 1) The northern area, with silicified sandstones and chalcedony for knapping and basalt for grinding; 2) The northeastern area, with silicified wood and silicified limestone for knapping and effusive rocks and granite for grinding; 3) The central area, with silicified limestones and chalcedony for knapping and basalt for grinding; 4) The south and southeastern area, with quartz and chalcedony for knapping and granitic and metamorphic rocks for grinding, and 5) The western area, dominated by silicified limestone for knapping and basalt and granite for grinding purposes. 
Further consideration of the second group of lithic procurement studies is facilitated by their further subdivision into two chronological research 'frameworks' (early hunter-gatherers and Middle and Late Holocene). While the lithic sources identified in these studies may have been used in different periods in the past, these subdivisions represent distinct research problems whose separate treatment helps to contextualise lithic procurement studies in the country.

\subsection{The early hunter-gatherers framework}

Towards the end of the nineties, a new interest in raw material sources emerged in Uruguayan archaeology. The renewed emphasis on the topic was the beginning of a research programme about hunter-gatherer technological organisation during the Late PleistoceneEarly Holocene transition in northern and northwestern Uruguay, developed by Rafael Suárez (e.g., 1999; 2004; 2010; 2011a; 2011b; 2015; Suárez in press; Suárez \& Piñeiro 2002). In Uruguay, Paleoamerican occupation is registered since at least ca. 12,000 BP (for early dates in the Southern Cone, see Beltrão 2000; Bueno et al. 2013; Méndez Melgar 2013; Prates et al. 2013; Suárez 2014; Suárez in press) and it is characterised by mobile hunter-gatherers exploring and colonising the plains, rockshelters and lowlands along the major rivers (e.g., Uruguay River, Negro River) that connect the interior of the continent (southern Brazil, northeastern Argentina) to the Atlantic coast (López Mazz 2013; Suárez 2015; Suárez in press). The growing focus on the archaeology of the 'First Americans' since the end of the last century brought new vigor to procurement studies in Uruguay.

The detailed survey of silicified sandstone and agate (potential and utilised) sources in the Catalán Chico River area by Suárez \& Piñeiro (2002; also Suárez 2010) shed new light on the surface sites discovered by Taddei in the fifties. This work focused on availability and knapping quality of the rocks, as well as on a visual characterisation of primary sources. A stratigraphic profile of silicified sandstone sources was presented (Suárez \& Piñeiro 2002: fig. 2; Suárez 2010: figs. $6 \&$ 7), and measurements were taken of banks, clastic dikes and boulders. The availability of other mineral resources, such as agate and chalcedony, was also observed as geodes infilling basaltic vacuoles. The authors conducted petrographic thinsection analysis of silicified sandstone and agate sources and archaeological artefacts, this being the first reported use of this technique in Uruguayan lithic analysis (it had already been applied to ceramic samples (Capdepont \& Castillo 2001)). Although a previous reference to this technique exists in Cabrera Pérez (1995: 42), it consists only in a brief mention of a geological report about a basaltic rock and it is not a systematic attempt to introduce thinsection petrography into lithic analysis. Previously, archaeologically-driven thin-section analysis had been carried out for silicified sandstone belonging to the same sedimentary basin (Paraná) in southeastern Brazil, advancing knowledge of how granulometry, clast sphericity and roundness influenced knapping quality, among other factors (Araujo 1992).

Besides methodological innovations, Suárez \& Piñeiro's (2002) work made a theoretical contribution to Uruguayan procurement studies, revising the character of Catalán Chico River sites in terms of hunter-gatherer settlement and technological organization (Nelson 1991). These sites were now interpreted as quarries and quarry-workshops, and the previously assigned 'simple' and 'monotonous' character of this industry was questioned in light of the reduction sequence products expected in these sites, as well as the presence of discarded bifaces. The presence of bifaces in different stages of reduction and the low frequency of complete secondarily-thinned forms suggested the possibility of tool preparation at the quarry before transportation to other sites, e.g., residential bases, logistical camps, etc. (Suárez \& Piñeiro 2002: 270-273; Suárez 2010: 38-46). 
Under the hypothesis of a regionally-organised technology that transcended specific localities and involved regional mobility and resource transport among Paleoamerican huntergatherers, Suárez continued to develop source surveys in northern and other regions of Uruguay. His research programme has involved mapping of primary and secondary, potential and utilised sources (Suárez 2004; 2010; 2011a; 2011b; 2015: fig. 1) and Geographical Information System (GIS) elaboration (Suárez \& Gillam 2008); excavation of an utilised source (Suárez 2010; 2011b); consideration of availability factors through outcrop and clast measurements, and documentation of topographic position, knapping quality and colour (Suárez 2004; 2011b). The 'Catalanes Nacientes Arroyo Arapey' archaeological region was defined (Suárez 2010; 2011a; 2011b; 2015; Suárez in press) (see Figure 2, C), composed of silicified sandstone and siliceous rocks and minerals such as translucent agate, chalcedony and jasper, among others. Based on translucent agate source analyses (e.g., clast size) and technological observations on artefacts, Suárez (2010; 2011a; 2011b) defined two Paleoamerican procurement strategies for northern and northwestern Uruguay $(c a$. 11,0008,500 BP): Local exploitation of cobbles near residential sites in the Middle Uruguay River and Cuareim River; and regional transport of prepared artefacts from the Catalanes Nacientes Arroyo Arapey source region (140-170 km away) (see Figure 3 1-A).

The latter strategy, that of long distance transport, was an issue that had already begun to be recognised by Ameghino and Figueira in the late nineteenth century. This topic was introduced to modern Pleistocene-Holocene transition procurement studies in Uruguay by Flegenheimer et al. (2003). The discovery of bifacial artefacts and flakes made with a reddish cherty material in surface and stratigraphic assemblages dated between 11,000 and 10,000 BP in the Argentinean Pampean region (Tandilia Range) (see Figure 2), led the authors to develop a survey of potential sources. Technological and raw material similarities between these artefacts and projectile points mostly found in the central region of Uruguay suggested a relationship between these regions. A macroscopic- and petrographic thin-section-based comparison with samples taken at three utilised silicified limestone sources from southern Uruguay confirmed this region as the source area for these artefacts, implying a transport distance of between 400 and $500 \mathrm{~km}$ (see Figure 3 4-C). Long distance transport could have implied extended social networks between early hunter-gatherers of the Southern Cone (e.g., Borrero \& Franco 1997; Favier Dubois et al. 2009; Flegenheimer et al. 2003; López Mazz et al. 2015; Suárez 2011b; Suárez in press).

Due to it having been transported over long distances, and highly utilised and curated (e.g., in different formal tools, after Andrefsky 1994), silicified limestone as a raw material has received special attention in recent years. Under the denomination "silicified limestone" are included here all carbonate rocks (e.g., limestones and calcretes) affected by silica replacement and cementation (see Bustillo 2010), including duricrusts or silcretes and other archaeologically relevant silica rocks grouped under the general term "chert" (following Luedtke 1992: 5). This resource, present in siliceous facies affecting limestones and calcretes (also sandstones) in western and southern Uruguay and northeastern Argentina (Entre Ríos Province) (see Figure 2), was available for humans in different morphologies, knapping quality values and colours (Loponte et al. 2011; Nami in press; Martínez et al. 2015). Its utility for determining provenance has been challenged by Loponte et al. (2011; also Martínez et al. 2015), whose thin-section and geochemical analysis could not differentiate Uruguayan from Argentinian sources. This work involved the first use of an instrumental technique for characterising materials from Uruguay, the LA-ICP-MS (Laser Ablation Inductively Coupled Plasma Mass Spectrometry). More recently, Batalla et al. (2013) have used GIS for documenting known sources of this rock as well as for determining new survey areas. 


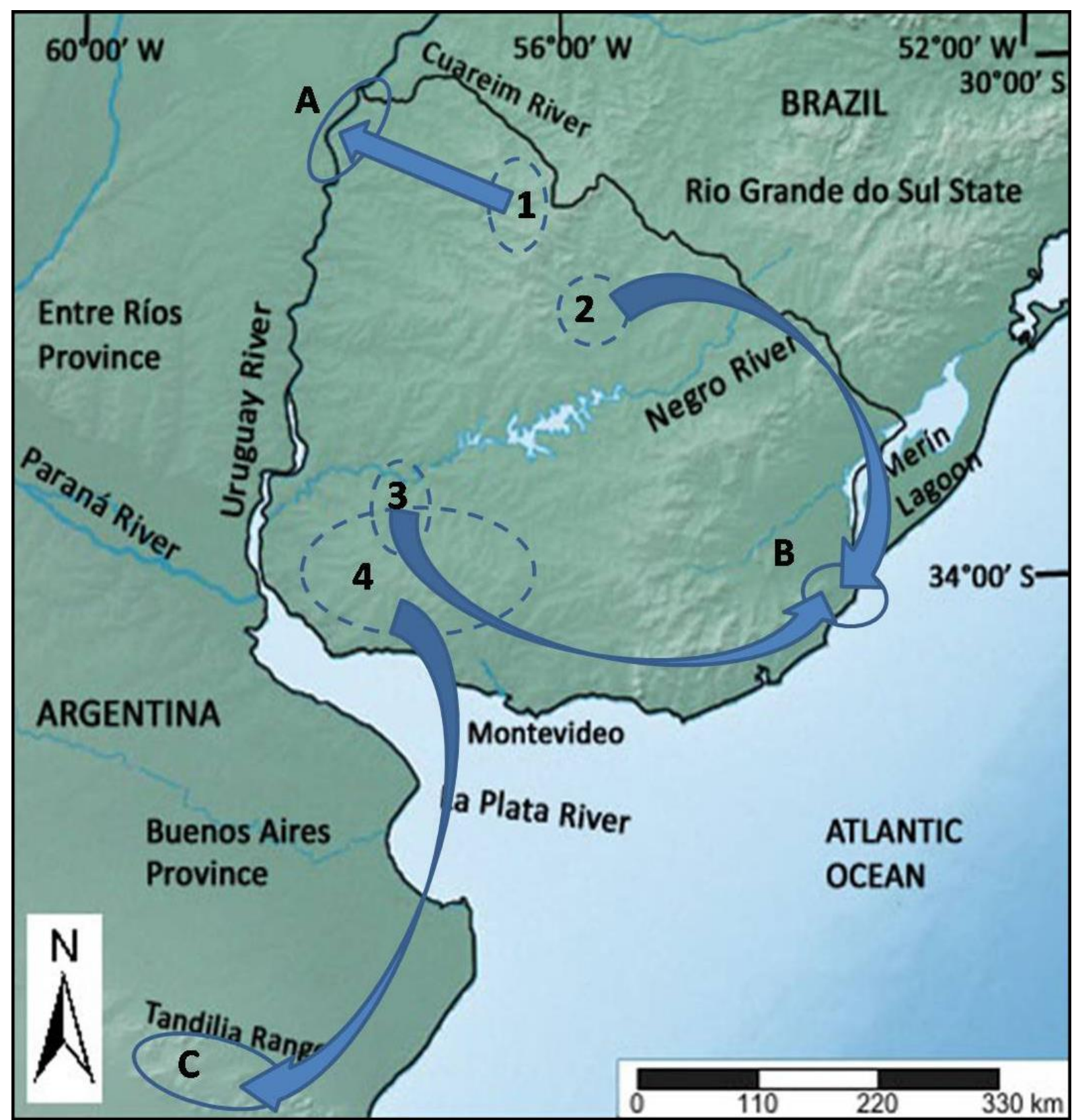

Figure 3. Raw material long distance transfers $(>100 \mathrm{~km})$ suggested for early hunter-gatherers in Uruguay. Circles and letters indicate areas with residential sites: A. Middle Uruguay River and Lower Cuareim River; B. Negra Lagoon basin; C. Tandilia Range. Dashed line circles and numbers indicate proposed source areas: 1. Catalanes-Arapey region; 2. Yaguarí Creek gravel deposits; 3. Grande Creek basin; 4. Southwest Uruguay. Arrows indicate proposed transfer distances: 1-A, for silicified sandstone and translucent agate (Suárez 2010; 2011b); 2-B and 3-B, for chalcedony and silicified limestone (López Mazz et al. 2011, but see discussion in the same article); 4-C, for silicified limestone (Flegenheimer et al. 2003).

Since the middle part of the last decade, procurement studies concerning the Paleoamerican settlement of Uruguay were reported in other regions of the country. The central region (see Figure 2, D) has attracted a particular interest for the long-recognised presence of so-called 'Fishtail' points and other early diagnostic artefacts among its surface assemblages (e.g., Baeza et al. 2001; Bosch et al. 1980; Castiñeira et al. 2011; Nami \& Castro 2014; Suárez 2003; 2009; 2011a; Taddei 1980b; 1987). Hugo Nami (e.g., 2007; 2009; 2013; Nami in press; Nami \& Castro 2014) has been documenting artefacts in private and public collections, developing technical observations on Paleoamerican reduction sequences (based on his experience as an experimental archaeologist) and conducting surveys and excavations 
in the Middle Negro River region since the 2000s. Nami $(2007 ; 2009 ; 2013$ : 15; Nami in press) reported primary and secondary sources of silicified limestone, crystal quartz and chalcedony, recording size range, morphologies of available clasts (e.g., tabular), knapping quality, and extraction scars in outcrops and associated artefacts. He also made some observations about raw material selectivity among early hunter-gatherers, paying attention to the reddish colour of the silicified limestones used for manufacturing most of the points and other artefacts (Nami in press), as well as on the translucency of crystal quartz (Nami 2013: 9). A pioneer study concerning raw material colour as a choice factor for Paleoamerican hunter-gatherers in the Argentinian Pampean region was made by Flegenheimer \& Bayón (1999; see also Colombo \& Flegenheimer 2013).

In the western section of the Middle Negro River basin, Andrés Gascue (2009; 2013) and collaborators (Duarte 2011; Gascue et al. 2013) developed source surveys and macroscopic and microscopic characterisation of different raw materials. A survey in the Grande creek and its main tributaries (see Figure 2, E), previously mentioned as a source area by Florines (2004), allowed Gascue (2009) to identify primary and secondary potential and utilised sources of silicified limestone and microcrystalline quartz, recording also topographic position, morphology, colour, knapping quality and extraction scars. Other sources have been reported and analysed in the same manner in the vicinity $(20 \mathrm{~km})$ of archaeological sites in the Negro basin (Gascue 2013; Gascue et al. 2013).

The early peopling of the country has also been a framework for source surveys and characterisation in the southeastern region, close to the Atlantic coast (see Figure 2, F). The earlier components of Rincón de los Indios (8,800-8,300 BP) have yielded artefacts made from different raw materials, from local quartz and quartzite to probably exotic siliceous resources (e.g., silicified limestone) (Gascue et al. 2009; López Mazz et al. 2009). Regional primary and secondary source surveys conducted by José López Mazz and colleagues (2011) have produced a database containing information about lithic raw materials from lagoon shores, the Atlantic coast, nearby hills and extra-regional $(>100 \mathrm{~km})$ sources (see Figure 32 -B and 3-B). A thin-section characterisation allowed the authors to better identify and even to rename some of the mineral resources previously described, showing the potential of this technique for lithic studies. Recently, López Mazz et al. (2015) made comparisons between the database and projectile points recovered in two early layers of the site, supporting past results of combined local and non-local lithic procurement, giving way to a greater emphasis on local sources towards the Holocene.

\subsection{The Middle and Late Holocene framework}

Different social changes among hunter-gatherer groups, including the incorporation of ceramic technology and horticulture, occurred in the Southern Cone at a time of important climatic changes during the Middle Holocene ( $c a$. 7,000-3,000 BP) (see revision in Politis 2008). As already mentioned, evidence of social intensification, and permanent settlements, alongside a reduction in mobility ranges, has been found in eastern Uruguay (Iriarte et al. 2004; López Mazz 2001). In the Middle Uruguay River region primary utilised sources of different raw materials were reported in the vicinity of rock art sites of a presumed Middle Holocene date, $c a$. 4,600 BP (Piñeiro 2010; see also Cabrera Pérez 2012). The Late Holocene (ca. 3,000-500 BP) records regional cultural diversification, which in Uruguay, northeastern and Pampean Argentina and southern Rio Grande do Sul (Brazil), resulted in the co-existence of fluvial, grassland and lagoon hunter-gatherer-fishers and horticulturalists with moundbuilders and other groups with different ceramic traditions (e.g., Guaraní) (Politis 2008). For the Late Holocene levels of the Guayacas site ( $c a .450$ BP), in the Lower Uruguay River, wider interaction networks implied through ceramic decoration was correlated with 
diminished residential mobility and embedded procurement, as informed by (among others) lithic source surveys and technological comparisons of lithic artefacts (Capdepont 2013; Lamas 2013).

Extending for more than $600 \mathrm{~km}$, the Uruguayan coast contains evidence of environmental and cultural changes between $c a .4,800$ and 2,000 BP (see discussion in Inda et al. 2011; Erchini et al. 2015), with sea level oscillations affecting coastal lifeways and procurement strategies. Lithic source surveys related to La Plata River-Atlantic coastal occupations can be traced back to the nineties, with mention of outcrops and cobbles in the western Montevideo shore (Martínez et al. 1994). Current research in the eastern La Plata River coast by Carina Erchini and colleagues (Erchini et al. 2011; Erchini et al. 2015) has broadened our understanding of potential lithic sources available to these groups, including continental and coastal (rounded pebbles and cobbles) resources. Using geological maps and source surveys (Baeza \& Sotelo 2013: 149), Marozzi et al. (2013) reported the exploitation of cobbles as the main procurement strategy for Middle Holocene (ca. 4,000 BP) sites in the western La Plata River (Colonia Department).

In Santa Lucía River basin (see Figure 2, G), adjacent to the littoral La Plata River, Laura Beovide (2004) and her team (Beovide \& Baeza 2007; Beovide \& Lemos 2007; 2011; Beovide et al. 2010) have reported different potential sources for sites dated ca. 4,800 BP and between $c a$. 2,500 and 400 BP. Using geological maps and general on-source observations, the authors recorded topographic positions, visibility in different geological periods (as interpreted by marine ingressions (Beovide \& Baeza 2007: 259-260)), knapping quality, and distances to archaeological sites of these lithic sources. An analytical application of GIS was introduced by Beovide \& Lemos (2011) for determining procurement distances between archaeological sites and amphibolite outcrops and secondary sources. A picture of different strategies emerged from these studies and comparisons with artefactual reduction sequences: The Middle Holocene components were more focused on sources further away $($ e.g., $>10 \mathrm{~km})$ than in the Late Holocene, a pattern which they related to an upper marine level inhibiting access to nearer coastal resources during this epoch (Beovide et al. 2010).

Raw material provenance of artefacts found in the cerritos de indios has been another matter of study in the last decade and a half. On the one hand, the source database for moundbuilders from eastern Uruguay has been increased with surveys in the hills (López Mazz \& Pintos 2001) and the Atlantic coast field dunes and rocky hills (López Mazz \& Gascue 2007), and has been further broadened and systematised (López Mazz et al. 2011). This database could be further enriched with mapping and source characterisation data recently obtained for the cerritos of nearby south Brazil (García \& Milheira 2013). On the other hand, a particular emphasis has been placed on mounds located in the northeastern and central region of the country, in the Yaguarí creek basin (see Figure 2, D), where an extensive GIS-based archaeological inventory involving these ( $c a .3,000 \mathrm{BP}$ ) and other sites was developed (Gianotti et al. 2005). Several potential sources were identified by López Mazz \& Gascue (2005: 127), in hills (primary sources) and river crossings (secondary sources), and knapping quality, outcrop and clast maximum size, abundance, and accessibility was documented. Petrographic similarities were subsequently found between samples taken at secondary sources of silicified sandstone and chalcedony, and artefacts excavated in a mound (Gascue \& López Mazz 2009).

\section{Perspectives: Database construction, standardisation and characterisation}

Lithic procurement was a topic of general interest for amateur and pioneer archaeologists working in Uruguay since the last decades of the nineteenth century, and their work resulted in the first observations, resource lists and on-source descriptions of lithic sources in the 
country. Professional archaeologists over the last thirty years incorporated the theoretical framework of technological organisation and lithic production systems, and produced the first source-oriented surveys and visual characterisation approaches. Microscopic studies, involving both thin-section petrography and geochemical instrumental techniques, were introduced in the present century.

Old topics and problems stimulate new perspectives and approaches. Old lithic lists have given place to regional resource databases in the context of different research questions. The utilization of GIS for documenting purposes is still a work in construction in several regions (Batalla et al. 2013; López Mazz \& Gascue 2005; Suárez \& Gillam 2008). The combination of both documenting and analytical applications of GIS has also begun to be explored (Batalla et al. 2013; Beovide \& Lemos 2007; 2011). In the former, on-source data concerning factors affecting procurement should be incorporated together with laboratory observations about outcrop samples and clast macroscopic and microscopic characteristics.

A standardisation in terminology used in on-source documenting, as well as in laboratory description of samples, is also desirable. Several terms have been borrowed from the geosciences, e.g., for the definition of source attributes (Suárez \& Pineiro 2002) and material re-denomination through thin-section analysis (López Mazz et al. 2011). The utilisation of sedimentological terms, such as the Udden-Wentworth grain-size scale for clast denomination (cobbles, pebbles, boulders) and clast shape terms (Nichols 2009) would be useful for description of availability, in particular for secondary sources. Clast counting and time expended, a methodology proposed by Franco \& Borrero (1999), would also be helpful for documenting and statistically comparing secondary sources (e.g., Alberti \& Cardillo 2015).

In recent times, the provenance issue has involved the use of thin-section analysis (Flegenheimer et al. 2003; Gascue \& López Mazz 2009; López Mazz et al. 2011; Suárez 2010; Suárez \& Piñeiro 2002). Analytical instrumental techniques for geochemical characterization, more recently incorporated by Loponte et al. (2011), are valuable resources yet to be explored. A consideration of specific techniques applicable to each raw material according to its mineralogical characteristics would be a good starting point for future discussions.

Finally, further consideration of non-technological aspects of raw material procurement could bring valuable new insights into lithic studies, for example, the importance of colour and textural features and social networks influencing long-distance transport, a point already noticed for Paleoamerican occupations (Flegenheimer et al. 2003; Nami 2013; Nami in press; Suárez 2010; 2011b; Suárez in press). By documenting this and other visual properties in a systematic manner for different periods and regions, other depiction of procurement strategies could be obtained. In the same guise, other technological issues could be addressed with the aid of microscopic use-wear analysis (for a review of these studies in Latin America see Mansur et al. 2014), by trying to assess correlations between raw material type and tool functional use, which in turn may have affected procurement strategies.

Discussion and consideration of these issues is important to the development and standardisation of lithic procurement studies in Uruguay going forward, and would ultimately help us to reach a better understanding of the richness of indigenous technology and culture in the Southern Cone.

\section{Acknowledgements}

This work was carried out while receiving CAPES (Coordenação de Aperfeiçoamento de Pessoal de Nível Superior) Masters grant. I thank two anonymous reviewers for comments to improve the paper and Jen Watling for help with the written English. 


\section{References}

Alberti, J. \& Cardillo, M. 2015, Primary and secondary lithic raw material sources along the western coast of San Matías Gulf (Río Negro province, Argentina): A first approach to their spatial variability. Quaternary International, 373: 63-71. doi:10.1016/j.quaint.2014.09.061

Ameghino, F. 1877, Noticias sobre Antigüedades Indias de la Banda Oriental. Con láminas fotográficas representando objetos de piedra de la Edad Neolítica. Imprenta de la Aspiración, Mercedes, 81 p. (in Spanish) ("Notes about Indian antiquities from Banda Oriental. With photographic plates representing stone objects of Neolithic Age")

Ameghino, F. 1918, La Antigüedad del Hombre en el Plata. La Cultura Argentina, Buenos Aires, 348 p. (in Spanish) ("The antiquity of man in La Plata River")

Andrefsky, W., Jr. 1994, Raw-material availability and the organization of technology. American Antiquity, 59(1): 21-34. URL: http://www.jstor.org/stable/3085499

Andrefsky, W., Jr. 2009, The analysis of stone tool procurement, production and maintenance. Journal of Archaeological Research, 17(1): 65-103. doi:10.1007/s10814008-9026-2

Araujo, A.G.M. 1992, As propriedades físicas dos arenitos silicificados e suas implicações na aptidão ao lascamento. Revista do Museu de Arqueologia e Etnologia, 2: 63-74. (in Portuguese) ("Physical properties of silicified sandstones and their implications for knapping quality")

Baeza, J. 1984, Elementos para una arqueología del Río Negro. Revista Antropológica, 3: 3441. (in Spanish) ("Elements for archaeology of the Negro River")

Baeza, J. 1985, Los fechados radiocarbónicos de Salto Grande. In: Estado actual de las investigaciones arqueológicas en el Uruguay. Vol. 1, Centro de Estudios Arqueológicos (CEA), Montevideo: p. 20-24. (in Spanish) ("The radiocarbon dates from Salto Grande")

Baeza, J. 1992, El aprovechamiento de las materias primas líticas en grupos prehistóricos. In: las Jornadas de Ciencias Antropológicas en el Uruguay: 23 al 27 de noviembre 1987, Ministerio de Educación y Cultura, Montevideo: p. 9-13. (in Spanish) ("Lithic raw material procurement among prehistoric groups")

Baeza, J. 2013, A propósito de algunas posibles relaciones con el NOA. Cuadernos del Instituto Nacional de Antropología y Pensamiento Latinoamericano - Series Especiales, 1(4): 75-80. (in Spanish) ("Some posible relationships with the Argentinian Northwest")

Baeza, J. \& Bosch, A. 1975, Algunos hallazgos de posible origen guaraní. In: II Congreso Nacional de Arqueología, III Encuentro de Arqueología del Litoral, Centro de Estudios Arqueológicos (CEA) \& Museo Municipal de Historia Natural de Río Negro, Fray Bentos: p. 1-10. (in Spanish) ("Some possible Guaraní finds")

Baeza, J., Femenías, J., Suárez, R., \& Florines, A. 2001, Investigación arqueológica en el Río Negro Medio. Informe preliminar. In: Arqueología uruguaya hacia el Fin del Milenio, Vol. 1. Gráficos del Sur, Montevideo: p. 285-295. (in Spanish) (“Archaeological research in the Middle Negro River. Preliminary report") 
Baeza, J. \& Sotelo, M. 2013, La etapa de control y seguimiento de obra. In: Estudio de Impacto Arqueológico y Cultural del proyecto construcción de una fábrica de celulosa y planta de energía eléctrica Punta Pereira, Conchillas, Departamento de Colonia (Brum, L. \& Lezama, A., Eds.), Departamento de Arqueología, ICA, Facultad de Humanidades y Ciencias de la Educación, Montevideo: p. 145-150. (in Spanish) ("Control and monitoring of the work")

Batalla, N. 2013. Las materias primas líticas del Río Negro Medio: Una aproximación a su aprovechamiento. Anuario de Arqueología del Uruguay, 2011-2012: 20-46. (in Spanish) ("Lithic raw materials from Middle Negro River: An approach to its exploitation")

Batalla, N., Cabrera, F. \& Detomasi, R. 2013, Disponibilidad de materias primas líticas para grupos indígenas: Una aproximación interdisciplinaria a las Calizas del Queguay. In: $V$ Jornadas de Investigación y IV de Extensión de Facultad de Humanidades y Ciencias de la Educación, Facultad de Humanidades y Ciencias de la Educación, Universidad de la República, Montevideo: p. 1-11. (in Spanish) ("Raw material availability for indigenous groups: An interdisciplinary approach to Queguay Limestones")

Bayón, C. \& Flegenheimer, N. 2003, Tendencias en el estudio del material lítico. In: Análisis, interpretación y gestión en la Arqueología de Sudamérica (Curtoni, R. \& Endere, M. L., Eds.), Serie Teórica Número 2. Investigaciones Arqueológicas y Paleontológicas del Cuaternario Pampeano (INCUAPA), Universidad Nacional del Centro de Provincia de Buenos Aires, Olavarría: p. 65-90. (in Spanish) ("Trends in lithic studies").

Bayón, C., Flegenheimer, N., Valente, M., \& Pupio, A. 1999, Dime cómo eres y te diré de dónde vienes: Procedencia de rocas cuarcíticas en la región pampeana. Relaciones de la Sociedad Argentina de Antropología, 24: 187-217. (in Spanish) ("Tell me how you are and I will tell you where you come from: Provenance of quartzite rocks in Pampean region")

Beltrão, M. C. 2000, Ensaio de arqueogeologia: Uma abordagem transdisciplinar. ZIT Gráfica e Editora, Rio de Janeiro, 170 p. (in Portuguese) (“An essay on archaeogeology: A transdisciplinary approach")

Beovide, L. 2004, Recursos y organización del espacio prehistórico costero en la cuenca inferior del Río Santa Lucía, Uruguay. In: X Congreso Uruguayo de Arqueología: La Arqueología Uruguaya ante los desafíos del nuevo siglo (Beovide, L., Barreto, I., \& Curbelo, C., Eds.), Asociación Uruguaya de Arqueología, Montevideo: p. 1-25. (in Spanish) ("Resources and organization of the prehistoric coastal space at the lower Santa Lucía River, Uruguay”)

Beovide, L. \& Baeza, J. 2007, Fuentes potenciales de materia prima lítica en el tramo medio del Río de la Plata: Un recurso constante en la dinámica costera. In: Arqueología en las Pampas (Bayón, C., Pupio, A., Gonzalez, M. I., Flegenheimer, N. \& Frère, M., Eds.), Sociedad Argentina de Antropología, Buenos Aires: p. 251-271. (in Spanish) ("Potential lithic raw material sources in the middle La Plata River coastline: A constant resource in coastal dynamics") 
Beovide, L. \& Caporale, M. 2001, Investigaciones en el Río Uruguay Medio: Análisis y redimensión de las colecciones provenientes de la Misión de Rescate Arqueológico de Salto Grande. In: Arqueología uruguaya hacia el Fin del Milenio, Vol. 1., Gráficos del Sur, Montevideo: p. 311-325. (in Spanish) ("Research in the Middle Uruguay River: Analysis and reconsideration of Salto Grande Archaeological Rescue Mission collections")

Beovide, L. \& Lemos, J. 2007, Kiyú: Una ventana al paleopaisaje y al uso del espacio en el curso medio del Río de la Plata para el Holoceno Tardío. In: XVI Congreso Nacional de Arqueología Argentina, Vol. 1 (Albeck, M. E., Ed.), Gabinete de Arqueología, Universidad Nacional de Jujuy, San Salvador de Jujuy: p. 157-162. (in Spanish) (“Kiyú: A window into paleolandscape and land use in the middle La Plata River during the Late Holocene")

Beovide, L. \& Lemos, J. 2011, Una aproximación al área de abastecimiento prehistórico de anfibolitas en la Costa Platense uruguaya: Estudio distribucional en base a GIS. In: Avances y perspectivas en la Arqueología del Nordeste (Feuillet, M., Colasurdo, B., Sartori, J. \& Escudero, S., Eds.), Municipalidad de Santo Tomé, Santa Fe: p. 145-155. (in Spanish) ("An approach to the amphibolite prehistoric procurement area in the Uruguayan La Plata River coastline: A distributional GIS-based study")

Beovide, L., Malán, M. \& Campos, S. 2010, Evolución costera y sistemas de producción lítica en el valle inferior del río Santa Lucía, Uruguay. In: Arqueología de cazadores recolectores en la Cuenca del Plata (1st ed.) (Cocco, G. \& Feuillet Terzaghi, M. R., Eds.), Centro de Estudios Hispanoamericanos, Santa Fe: p. 135-155. (in Spanish) ("Coastal evolution and lithic production systems at the Santa Lucía River lower valley, Uruguay")

Binford, L. 1979, Organization and Formation Processes: Looking at Curated Technologies. Journal of Anthropological Research 35(3): 255-273.

URL: http://www.jstor.org/stable/3629902

Blasco, J., Gazzán, N., Lamas, G., Tabárez, P. \& Gianotti, C. 2011, La industria lítica de los constructores de cerritos de Pago Lindo, Tacuarembó. Departamento de Publicaciones, Facultad de Humanidades y Ciencias de la Educación, Montevideo, 20 p. (in Spanish) ("Lithic industry of Pago Lindo moundbuilders, Tacuarembó")

Bórmida, M. 1964, Las industrias líticas precerámicas del Arroyo Catalán Chico y del Río Cuareim (Departamento de Artigas, R.O. del Uruguay). Revista di Scienze Preistoriche, 19(1-4): 195-232. (in Spanish) ("The pre-ceramic lithic industries from Catalán Chico River and Cuareim River (Artigas Department, Uruguay) ")

Borrero, J. L. \& Franco, N. 1997, Early Patagonian hunter-gatherers: Subsistence and technology. Journal of Anthropological Research, 53(2): 219-239.

URL: http://www.jstor.org/stable/3631277

Bosch, A., Femenías, J., \& Olivera, A. 1980, Dispersión de las puntas líticas “pisciformes” en el Uruguay. In: Anales del III Congreso Nacional de Arqueología y IV Encuentro de Arqueología del Litoral, Centro de Estudios Arqueológicos (CEA), Montevideo: p. 118. (in Spanish) ("Dispersion of pisciform projectile points in Uruguay")

Bracco, R., Cabrera, L. \& Lopez Mazz, J. M. 2000, La Prehistoria de las Tierras Bajas de la Cuenca de la Laguna Merín. In: Arqueología de las Tierras Bajas (Duran, A. \& Bracco, R., Eds.), Ministerio de Educación y Cultura, Montevideo: p. 14-38. (in Spanish) ("The prehistory of Merín Lagoon Basin lowlands") 
Bueno, L., Dias, A. S., \& Steele, J. 2013, The Late Pleistocene/Early Holocene archaeological record in Brazil: A geo-referenced database. Quaternary International 301: 74-93. doi:10.1016/j.quaint.2013.03.042

Bustillo, M. A. 2010, Silicification of continental carbonates. In: Carbonates in Continental Settings: Geochemistry, Diagenesis and Applications (Alonso-Zarza, A. M. \& Tanner, L. H., Eds.), Developments in Sedimentology, Vol. 62. Elsevier, Amsterdam: p. 153178. doi:10.1016/S0070-4571(09)06203-7

Cabrera Pérez, L. 1994, Subsistema tecnológico y estrategias adaptativas en el Río Uruguay Medio. In: Arqueología de Cazadores-Recolectores: Límites, casos y aperturas (Lanata, J. L. \& Borrero, L. A., Eds.), Programa de Estudios Prehistóricos, Buenos Aires: p. 4149. (in Spanish) ("Technological subsystem and adaptive strategies in the Middle Uruguay River")

Cabrera Pérez, L. 1995, La cueva "Casa del Diablo", Sierra de San Miguel (Rocha, Uruguay). In: Arqueología en el Uruguay: 120 años después (Consens, M., López Mazz, J. M. \& Curbelo, C., Eds.), Surcos, Montevideo: p. 40-47. (in Spanish) (“The 'Casa del Diablo' cave, San Miguel hills (Rocha, Uruguay)")

Cabrera Pérez, L. 2004, Marcos teóricos y criterios dominantes en las tipologías líticas uruguayas. In: Teoría arqueológica en América del Sur (Politis, G. G. \& Pereti, R., Eds.), Serie Teórica Número 3. Investigaciones Arqueológicas y Paleontológicas del Cuaternario Pampeano (INCUAPA), Universidad Nacional del Centro de Provincia de Buenos Aires, Olavarría: p. 185-196. (in Spanish) ("Theoretical frameworks and dominant criteria in the Uruguayan lithic typologies")

Cabrera Pérez, L. 2012, Arte rupestre temprano en el norte del Uruguay. In: L'art pléistocène dans le monde. Actes du Congrès IFRAO (Clottes, J., Ed.), Société Préhistorique Ariège-Pyrénées, Tarascon-sur-Ariège: p. 735-750. (in Spanish) ("Early rock art in northern Uruguay")

Capdepont, I. 2013, Arqueología de sociedades indígenas del litoral del Río Uruguay. Paisajes y ocupaciones humanas. Publicia, Saarbrücken, 313 p. (in Spanish) ("Archaeology of indigenous societies from the Uruguay River littoral")

Capdepont, I. \& Castillo, A. 2001, Caracterización cerámica para una interpretación antropológica. In: Arqueología uruguaya hacia el Fin del Milenio, Vol. 1. Gráficos del Sur, Montevideo: p. 403-416. (in Spanish) ("Ceramic characterisation for an anthropological interpretation")

Castillo, A. 2004, Excavación y museo: Profundizando en el conocimiento de los grupos ceramistas del litoral (Río Negro, Uruguay). In: X Congreso Uruguayo de Arqueología: La Arqueología Uruguaya ante los desafíos del nuevo siglo (Beovide, L., Barreto, I., \& Curbelo, C., Eds.), Asociación Uruguaya de Arqueología, Montevideo: p. 1-15. (in Spanish) ("Excavation and museum: Broadening the knowledge about littoral ceramist groups (Río Negro, Uruguay)”)

Castiñeira, C., Cardillo, M., Charlin, J., \& Baeza, J. 2011, Análisis de morfometría geométrica en puntas Cola de Pescado del Uruguay. Latin American Antiquity, 22(3): 335-358. (in Spanish) ("Geometric morphometric analysis of Fishtail Points from Uruguay”). URL: http://www.jstor.org/stable/23072526 
Centro de Estudios Arqueológicos (CEA) 1977, Investigaciones arqueológicas en el área de Salto Grande: Tres primeros radiocarbonos. In: V Encuentro de Arqueología del Litoral, Centro de Estudios Arqueológicos (CEA) \& Museo Municipal de Historia Natural, Fray Bentos: p. 68-88. (in Spanish) ("Archaeological investigations in the Salto Grande area: The three first radiocarbon dates")

Chebataroff, J. 1955, Evolución del relieve del Uruguay y de Río Grande del Sur. Revista Uruguaya de Geografía, 8: 39-96. (in Spanish) ("Relief evolution of Uruguay and Río Grande del Sur")

Chebataroff, J. 1962, El yacimiento lítico prehistórico del Arroyo Catalán Chico. Revista Nacional, 210: 1-16. (in Spanish) ("The lithic prehistoric site of Catalán Chico River")

Church, T. (Ed.) 1994, Lithic Resource Studies: A Sourcebook for Archaeologists. Department of Anthropology, University of Tulsa, Tulsa, p. 255.

Colombo, M. 2013, Los cazadores y recolectores pampeanos y sus rocas. La obtención de materias primas líticas vista desde las canteras arqueológicas del centro de Tandilia. Ph.D thesis, thesis no. 1273 at the Facultad de Ciencias Naturales y Museo, Universidad de La Plata, La Plata, 482 p. (in Spanish) ("Pampean hunter-gatherers and their rocks. Lithic raw material procurement as seen from the archaeological quarries of central Tandilia")

Colombo, M. \& Flegenheimer, N. 2013, La elección de rocas de colores por los pobladores tempranos de la Región Pampeana (Buenos Aires, Argentina). Nuevas consideraciones desde las canteras. Boletín del Museo Chileno de Arte Precolombino, 18(1): 125-137. (in Spanish) ("The selection of coloured rocks by early settlers in the Pampean Region (Buenos Aires, Argentina). New considerations from the quarries")

Consens, M. 2001, Revisión conceptual: Cambios en el análisis lítico del noroeste uruguayo. In: Arqueología uruguaya hacia el Fin del Milenio, Vol. 1. Gráficos del Sur, Montevideo: p. 417-431. (in Spanish) ("A conceptual revision: Changes in the Uruguayan northwest lithic analysis")

Cordero, S. 1960, Los Charrúas: Síntesis etnográfica y arqueológica del Uruguay. Mentor, Montevideo, 323 p. (in Spanish) ("The Charrúas: An ethnographic and archaeological synthesis of Uruguay")

Curbelo, C. 2004, Reflexiones sobre el desarrollo del pensamiento teórico en la arqueología uruguaya. In: Teoría arqueológica en América del Sur (Politis, G.G., \& Pereti, R., Eds.), Serie Teórica Número 3 Investigaciones Arqueológicas y Paleontológicas del Cuaternario Pampeano (INCUAPA), Universidad Nacional del Centro de Provincia de Buenos Aires, Olavarría: p. 259-279. (in Spanish) ("Reflections on the development of theoretical thought in Uruguayan archaeology")

Curbelo, C. \& Martínez, E. 1992, Aprovechamiento de materias primas líticas para un área relacionada con la Sierra de San Miguel, Departamento de Rocha, ROU. In: Ediciones del Quinto Centenario, Vol. 1, Estudios Antropológicos. Facultad de Humanidades y Ciencias de la Educación, Montevideo: p. 123-139. (in Spanish) ("Lithic raw material procurement in the San Miguel hills area, Rocha Department, ROU")

Demaría, A. J. 1932, Anzuelos líticos prehispánicos del Uruguay. Revista de la Sociedad Amigos de la Arqueología, 6: 191-196. (in Spanish) ("Pre-Hispanic lithic fish hooks from Uruguay") 
Duarte, C. 2011, Análisis tecnológico lítico de lascas, núcleos e instrumentos tallados del sitio "La Lengua" (Río Negro Medio). (unpublished) Monographic work, Facultad de Humanidades y Ciencias de la Educación, Universidad de la República, Montevideo: 102 p. (in Spanish) ("Lithic technological analysis of flakes, cores and knapped tools from "La Lengua" site")

Erchini, C., Baeza, J., Tobella, M., Sosa, M., Ferrari, A. 2011, Investigaciones Arqueológicas en la Cuenca del Arroyo Solís Chico, Canelones, Uruguay. In: IV Jornadas de Investigación y III Jornadas de Extensión de la Facultad de Humanidades y Ciencias de la Educación, Facultad de Humanidades y Ciencias de la Educación, Montevideo: p. 114. (in Spanish) ("Archaeological research in the Solís Chico creek basin, Canelones, Uruguay")

Erchini, C., Ferrari, A., Tobella, M. \& Sosa, M. 2015, Looking at the sea: Mt Site, River Plate Coast, Canelones, Uruguay. Quaternary International, 373: 34-44. doi:10.1016/j.quaint.2015.02.029

Ericson, J. E. 1984, Towards the Analysis of Lithic Production Systems. In: Prehistoric Quarries and Lithic Production (Ericson, J. E. \& Purdy, B. A., Eds.), Cambridge University Press, New York: p. 1-9.

Favier Dubois, C., Stern, C. \& Cardillo, M. 2009, Primera caracterización de los tipos de obsidiana presentes en la costa rionegrina. In: Arqueología de la Patagonia: Una mirada desde el último confín (Salemme, M., Santiago, F., Alvarez, M., Piana, E., Vázquez, M. \& Mansur, E., Eds.), Editorial Utopías, Ushuaia: p. 349-359. (in Spanish) ("First charactersation of obsidian types from Río Negro coast")

Femenías, J. 1985, Las piedras grabadas de la región de Salto Grande (Uruguay y Argentina). Parte 1. Comunicaciones antropológicas del Museo de Historia Natural de Montevideo, 2(2): 1-34. (in Spanish) ("The engraved stones from Salto Grande region (Uruguay and Argentina). Part 1")

Figueira, J. H. 1892, Los primitivos habitantes del Uruguay. In: El Uruguay en la exposición histórico americana de Madrid. Memoria de los trabajos realizados por la Comisión Nacional encargada de organizar los elementos de concurrencia, Comisión de Exposición Histórico-Americana \& Imprenta Artística, Montevideo: p. 119-129. (in Spanish) ("The primitive inhabitants of Uruguay")

Figueira, J. H. 1900a, Chanás. In: Diccionario Geográfico del Uruguay (Araujo, O., Ed.), Imprenta Artística de Dornaleche y Reyes, Montevideo: p. 222-223. (in Spanish) ("The Chanás")

Figueira, J. H. 1900b, Charrúas. In: Diccionario Geográfico del Uruguay (Araujo, O., Ed.), Imprenta Artística de Dornaleche y Reyes, Montevideo: p. 224-230. (in Spanish) ("The Charrúas")

Figueira, J. H. 1900c, Paraderos. In: Diccionario Geográfico del Uruguay (Araujo, O., Ed.), Imprenta Artística de Dornaleche y Reyes, Montevideo: p. 564-566. (in Spanish) ("Sites")

Flegenheimer, N. \& Bayón, C. 1999, Abastecimiento de rocas en sitios pampeanos tempranos: Recolectando colores. In: En los tres reinos: Prácticas de recolección en el Cono Sur de América (Aschero, C., Korstanje, A. \& Vuoto, P., Eds.), Magna Publicaciones, Tucumán: p. 95-107. (in Spanish) ("Rock procurement in early Pampean sites: Gathering colours") 
Flegenheimer, N., Bayón, C., Valente, M., Baeza, J. \& Femenías, J. 2003, Long distance tool stone transport in the Argentine Pampas. Quaternary International, 109-110: 49-64. doi:10.1016/S1040-6182(02)00202-1

Florines, A. 2004, Relevamiento arqueológico de la localidad rupestre del Arroyo Chamangá, Flores. In: X Congreso Uruguayo de Arqueología: La Arqueología Uruguaya ante los desafíos del nuevo siglo (Beovide, L., Barreto, I., \& Curbelo, C., Eds.), Asociación Uruguaya de Arqueología, Montevideo: p. 1-32. (in Spanish) ("Archaeological survey at the Chamangá creek, Flores, rock art locality")

Franco, N. \& Borrero, J. L. 1999, Metodología de análisis de la estructura regional de recursos líticos. In: En los tres reinos: Practicas de recolección en el Cono Sur de America (Aschero, C. A., Korstanje, A. \& Vuoto, P., Eds.), Magna Publicaciones, Tucumán: p. 27-37. (in Spanish) ("Methodology for the analysis of the regional lithic resource structure")

García, A. M. \& Milheira, R. G. 2013, Gestão de fontes de matéria-prima lítica pelos Construtores de Cerritos no sul do Brasil: Um estudo de caso. Espaço Ameríndio, 7(1): 10-36. (in Portuguese) ("Lithic raw material source management by moundbuilders of southern Brazil: A case study")

Gascue, A. 2009, Tecnología lítica y patrones de asentamiento en la cuenca de Arroyo Grande (Soriano). In: Arqueología prehistórica uruguaya en el siglo XXI (López Mazz, J. M. \& Gascue, A., Eds.), Biblioteca Nacional, Facultad de Humanidades y Ciencias de la Educación (FHUCE), Montevideo: p. 133-150. (in Spanish) ("Lithic technology and settlement patterns in Grande creek basin (Soriano)")

Gascue, A. 2013, Aspectos estratigráficos y tecnológicos de las ocupaciones humanas prehistóricas en la localidad arqueológica Paso del Puerto (Río Negro, Uruguay). Cazadores Recolectores del Cono Sur. Revista de Arqueología, 6: 87-100. (in Spanish) ("Stratigraphic and technological aspects of prehistoric human occupations at the Paso del Puerto locality (Río Negro, Uruguay)”)

Gascue, A., Baeza, J., \& Bortolotto, N. 2013, Ocupaciones tempranas en el Río Negro Medio (Uruguay): Conjuntos artefactuales asociados a Cola de Pescado en el sitio Navarro. Cuadernos del Instituto Nacional de Antropología y Pensamiento Latinoamericano Series Especiales, 1(4): 236-248. (in Spanish) ("Early occupations in the Middle Negro River: Artefactual assemblages associated to Fishtail points at the Navarro site")

Gascue, A. \& López Mazz, J. M. 2009, Aprovisionamiento de materias primas líticas entre los constructores de cerritos del valle del Arroyo Yaguarí (Dpto. Tacuarembó). In: Arqueología Prehistórica Uruguaya en el Siglo XXI (López Mazz, J. M. \& Gascue, A., Eds.), Biblioteca Nacional, Facultad de Humanidades y Ciencias de la Educación (FHUCE), Montevideo: p. 101-115. (in Spanish) ("Lithic raw material procurement among mound builders from Yaguarí creek valley (Tacuarembó Department)")

Gascue, A., López Mazz, J. M., Villarmarzo, E., De León, N., Sotelo, M., \& Alzugaray, S. 2009, La organización de la tecnología lítica de los pobladores tempranos del este de Uruguay. Intersecciones en Antropología, 10: 63-73. (in Spanish) ("Lithic technological organization of the early inhabitants from eastern Uruguay")

URL: http://ref.scielo.org/vhwcvy

Geranio, S. 1939, Objetos en piedra y cerámica de antigua industria india hallados en territorio uruguayo. Dirección General de la Enseñanza Industrial, Montevideo: 21 p. (in Spanish) (“Ancient stone and ceramic indigenous objects found in Uruguay") 
Gianotti, C., Barreiro, D., Parcero, C., Otero, C., Amado, S. 2005, La construcción del inventario arqueológico del valle del Yaguarí. In: Traballos en Arqueoloxía da Paisaxe 36 (Gianotti, C., Ed.), Laboratorio de Arqueología da Paisaxe, Instituto de Estudos Galegos Padre Sarmiento, Santiago de Compostela: p. 27-47. (in Spanish) ("The construction of an archaeological inventory in Yaguarí creek valley")

Guidon, N. 1987, Historial del proyecto. In: Misión de Rescate Arqueológico, Salto Grande, Vol. 1 (Trakalo, R., Ed.), Ministerio de Educación y Cultura, Montevideo: p. 11-22. (in Spanish) ("Background of the project")

Guidon, N. 1989, Los sitios de las islas. El sitio Y58. In: Misión de Rescate Arqueológico, Salto Grande, Vol. 2 (Trakalo, R., Ed.), Ministerio de Educación y Cultura, Montevideo: p. 433-572. (in Spanish) ("The island sites. The Y58 site")

Haury, C. E. 1995, Defining lithic procurement terminology. In: Lithic Resource Studies: A Sourcebook for Archaeologists (Church, T., Ed.), Department of Anthropology, University of Tulsa, Tulsa: p. 26-31.

Hilbert, K. 1991, Aspectos de la arqueología en el Uruguay. Verlag Philipp von Zabern, Mainz am Rhein, 193 p. (in Spanish) (“Aspects of archaeology in Uruguay”)

Houot, A. 1987, Resultados de los trabajos arqueológicos anteriores en la región del proyecto y áreas vecinas. In: Misión de Rescate Arqueológico, Salto Grande, Vol.1 (Trakalo, R., Ed.), Ministerio de Educación y Cultura, Montevideo: p. 145-216. (in Spanish) ("Results of previous archaeological work in the project area and nearby")

Inda, H., Del Puerto, L., Bracco, R., Castiñeira, C., Capdepont, I., Gascue, A. \& Baeza, J. 2011, Relación hombre-ambiente para la costa estuarina y oceánica de Uruguay durante el Holoceno. Reflexiones y perspectivas. In: El Holoceno en la zona costera de Uruguay (García Rodríguez, F., Ed.), Comisión Sectorial de Investigación CientíficaUniversidad de la República, Montevideo: p. 229-260. (in Spanish) ("Humanenvironment relationships in the estuarine and oceanic coast of Uruguay. Reflections and perspectives")

Iriarte, J. 2000, Organización de la tecnología lítica en la costa Atlántica de los humedales de Rocha. In: Arqueología de las Tierras Bajas (Duran, A. \& Bracco, R., Eds.), Ministerio de Educación y Cultura, Montevideo: p. 71-82. (in Spanish) ("Lithic technological organization in the Atlantic coast at the Rocha wetlands")

Iriarte, J., Holst, I., Marozzi, O., Listopad, C, Alonso, E., Rinderknecht, A. \& Montaña, J. 2004, Evidence for cultivar adoption and emerging complexity during the mid-Holocene in the La Plata Basin. Nature, 432: 614-17. doi:10.1038/nature02983

Iriarte, J. \& Marozzi, O. 2009, Análisis del material lítico del sitio de Los Ajos. In: La arqueología como profesión: Los primeros 30 años. XI Congreso Nacional de Arqueología Uruguaya (Beovide, L., Erchini, C. \& Figueiro, G., Eds.), Asociación Uruguaya de Arqueología, Montevideo: p. 183-201. (in Spanish) ("Lithic analysis of Los Ajos site")

Jochim, M. A. 1979, Breaking down the system: Recent ecological approaches in archaeology. Advances in Archaeological Method and Theory, 2: 77-117. URL: http://www.jstor.org/stable/20170143

Kuhn, S. L. 1990, A geometric index of reduction for unifacial stone tools. Journal of Archaeological Science, 17: 583-593. doi:10.1016/0305-4403(90)90038-7 
Lamas, G. 2013, Análisis tecno-morfológico de materiales líticos del sitio Guayacas, Departamento de Paysandú. Anuario de Arqueología del Uruguay, 2011-2012: 176-207. (in Spanish) ("Tecno-morphological analysis of lithic artefacts from the Guayacas site")

Lemos, J. \& Duarte, C. 2013, La Tuna "hace poco": Una aproximación al sistema de producción lítica del sitio Puerto La Tuna (Uruguay) hacia ca. 400 años C14 AP. Cuadernos del Instituto Nacional de Antropología y Pensamiento Latinoamericano Series Especiales, 1(2): 253-263. (in Spanish) ("La Tuna "not long ago": An approach to the lithic production system of the Puerto La Tuna site (Uruguay), ca. 400 years ${ }^{14} \mathrm{C}$ BP”)

López Mazz, J. M. 2001, Las estructuras tumulares (cerritos) del litoral atlántico uruguayo. Latin American Antiquity, 12(3): 231-255. (in Spanish) ("The mound structures (Cerritos) from the Uruguayan Atlantic littoral").

URL: http://www.jstor.org/stable/971631

López Mazz, J. M. 2013, Early human occupation of Uruguay: Radiocarbon database, archaeological implications. Quaternary International, 301: 94-103. doi:10.1016/j.quaint.2012.07.004

López Mazz, J. M. \& Gascue, A. 2005, Aspectos de las tecnologías líticas desarrolladas por los grupos constructores de cerritos del arroyo Yaguarí. In: Traballos en Arqueoloxía da Paisaxe 36 (Gianotti, C., Ed.), Laboratorio de Arqueología da Paisaxe, Instituto de Estudos Galegos Padre Sarmiento, Santiago de Compostela: p. 123-144. (in Spanish) ("Aspects of the lithic technologies developed by mound builders groups from Yaguarí creek")

López Mazz, J. M. \& Gascue, A. 2007, El valle del arroyo Balizas: Estructuras monticulares y sitios del litoral atlántico uruguayo. Cazadores-Recolectores del Cono Sur, 2: 89-103. (in Spanish) ("The Balizas creek valley: Earthen mounds and sites from the Uruguayan Atlantic littoral")

López Mazz, J. M., Gascue, A. \& Piñeiro, G. 2011, Flint procurement strategies of the early hunter-gatherers of eastern Uruguay. In: Proceedings of the 2nd International Conference of the UISPP Commission on Flint Mining in Pre-and Protohistoric Times (Madrid, 14-17 October 2009) (Capote, M., Consuegra, S., Díaz-del-Río, P. \& Terradas, X., Eds.), BAR International Series Vol. 2260, Archaeopress, Oxford: p. 291302.

López Mazz, J. M., Marozzi, O. \& Aguirrezábal, D. 2015, Lithic raw material procurement for projectiles points in the prehistory of Uruguay. Journal of Lithic Studies, 2(1): 8395. doi:10.2218/jls.v2i1.1171

López Mazz, J. M., Nadal, O., Suárez, X., De León, V. \& Salvo, X. 2009, La gestión regional de los recursos minerales en las tierras bajas del Este: El espacio como variable de la producción lítica. In: La arqueología como profesión: Los primeros 30 años. XI Congreso Nacional de Arqueología Uruguaya (Beovide, L., Erchini, C. \& Figueiro, G., Eds.), Asociación Uruguaya de Arqueología, Montevideo: p. 473-485. (in Spanish) ("Mineral resource regional management in the eastern lowlands: Space as a variable of lithic production")

López Mazz, J. \& Pintos, S. 2001, El paisaje arqueológico de la Laguna Negra. In: Arqueología uruguaya hacia el Fin del Milenio, Vol. 1. Gráficos del Sur, Montevideo: p. 175-186. (in Spanish) (“The archaeological landscape of the Negra Lagoon”) 
Loponte, D., Tchillinguirian, P. \& Sacur, R. 2011, Caracterización de afloramientos de calizas silicificadas de la Provincia de Entre Ríos (Argentina) y su vinculación con los circuitos de abastecimiento prehispánico. In: Avances y perspectivas en la arqueología del Nordeste (Feuillet, M., Colasurdo, B., Sartori, J. \& Escudero, S., Eds.), Municipalidad de Santo Tomé, Santa Fe: p. 145-156. (in Spanish) ("Characterisation of silicified limestone from Entre Ríos Province (Argentine) and their relationship with preHispanic procurement circuits")

Luedtke, B. E. 1979, The identification of sources of chert artifacts. American Antiquity, 44(4): 744-757. URL: http://www.jstor.org/stable/279116

Luedtke, B. E. 1992, An Archaeologist's Guide to Chert and Flint. UCLA Institute of Archaeology, Los Angeles, 153 p.

Maeso, C. 1977, Investigaciones arqueológicas. In: Investigaciones arqueológicas (Tuya de Maeso, L., Ed.), Imprenta Don Bosco, Montevideo: p. 9-180. (in Spanish) ("Archaeological investigations")

Magnin, L. 2015, Hunter-gatherer provisioning strategies in a landscape with abundant lithic resources (La Primavera, Santa Cruz, Argentina). Quaternary International, 375: 55-71. doi:10.1016/j.quaint.2014.11.064

Mansur, M. E., De Ángelis, H., Alonso Lima, M. 2014, Microscopic use-wear analysis in Latin America: its contributions to new problems, raw materials and taphonomic contexts. In: Traceology Today: Methodological Issues in the Old World and the Americas (Mansur, M. E., Alonso Lima, M. \& Maigrot, Y., Eds.), BAR International Series Vol. 2643, Archaeopress, Oxford: p. 75-84.

Marozzi, O., Sotelo, M., Lamas, G., Gazzán, N. \& Ferrari, A. 2013, Análisis del material lítico del sitio Punta Pereira. In: Estudio de Impacto Arqueológico y Cultural del proyecto construcción de una fábrica de celulosa y planta de energía eléctrica Punta Pereira, Conchillas - Departamento de Colonia (Brum, L. \& Lezama, A., Eds.), Departamento de Arqueología, ICA, Facultad de Humanidades y Ciencias de la Educación, Montevideo: p. 129-134. (in Spanish) ("Lithic analysis of the Punta Pereira site")

Martínez, E. \& Curbelo, C. 1994, Teoría y método en las clasificaciones líticas de la Cuenca de la Laguna Merín. In: Arqueología de Cazadores-Recolectores: Límites, casos y aperturas (Lanata, J. L. \& Borrero, L. A., Eds.), Programa de Estudios Prehistóricos, Buenos Aires: p. 65-74. (in Spanish) ("Theory and method in lithic classifications at the Merín Lagoon Basin")

Martínez, E., Cabrera, L., Fusco, N. \& Curbelo, C. 1994, Informe primario de la prospección arqueológica de la costa oeste del Departamento de Montevideo. In: Relevamiento, diagnóstico y rescate arqueológico en el área de Punta Espinillo (Dpto. Montevideo) (López Mazz, J.M., Ed.), Facultad de Humanidades y Ciencias de la Educación, Montevideo: p. 139-142. (in Spanish) ("Primary report of the archaeological survey in the western shore of Montevideo Department")

Martínez, S., Veroslavsky, G. \& Cabrera, F. 2015, Calizas del Queguay: Un enfoque hacia la arqueología. Revista de Antropología del Museo de Entre Ríos, 1(2): 1-10. (in Spanish) ("Queguay Limestones: An archaeology-oriented approach")

Maruca Sosa, R. 1957, La Nación Charrúa. Imprenta Letras, Montevideo, 319 p. (in Spanish) ("The Charrúa nation") 
Melgar, W., Rodríguez, O. \& Femenías, J. 1975, Comunicación preliminar sobre el material lítico descubierto en la Isla de Arriba. In: II Congreso Nacional de Arqueología, III Encuentro de Arqueología del Litoral, Vol. 2, Centro de Estudios Arqueológicos (CEA) \& Museo Municipal de Historia Natural de Río Negro, Fray Bentos: p. 289-312. (in Spanish) ("Preliminary communication about lithic materials discovered in Isla de Arriba")

Méndez Melgar, C. 2013, Terminal Pleistocene/early Holocene ${ }^{14} \mathrm{C}$ dates form archaeological sites in Chile: Critical chronological issues for the initial peopling of the region. Quaternary International, 301: 60-73. doi:10.1016/j.quaint.2012.04.003

Meneghin, U. 1970, Comunicaciones preliminares sobre las industrias líticas del Cerro de los Burros. Centro de Estudios Arqueológicos (CEA), Montevideo, 24 p. (in Spanish) ("Preliminary comunication about lithic industries from Cerro de los Burros")

Meneghin, U. 1977, Nuevas investigaciones en los yacimientos del "Cerro de los Burros". Edición del Autor, Montevideo, 26 p. (in Spanish) ("New investigations at the "Cerro de los Burros" sites")

Meneghin, U. 2004, Artefactos líticos excepcionales del Uruguay. Orígenes, 1: 1-17. (in Spanish) ("Excepcional lithic artefacts from Uruguay")

Meneghin, U. 2006, El antropolito de Mercedes. Orígenes, 4: 1-23. (in Spanish) (“The antropolith from Mercedes")

Meneghin, U. 2007, Itaizás del Uruguay. Orígenes, 6: 1-35. (in Spanish) (“Itaizás from Uruguay")

Meneghin, U. 2011, Observaciones sobre algunos artefactos líticos discoidales registrados en el Uruguay. Orígenes, 10: 1-33. (in Spanish) (“Observations about some lithic discoidal artefacts found in Uruguay")

Meneghin, U. 2015, Secuencia cronoestratigráfica de Urupez II. Nuevas dataciones radiométricas. Orígenes, 13: 1-19. (in Spanish) ("Chronostratigraphic sequence of Urupez II. New radiometric dates")

Nami, H. G. 2001, Consideraciones tecnológicas preliminares sobre los artefactos líticos de Cerro de los Burros (Maldonado, Uruguay). Comunicaciones Antropológicas de los Museos Nacionales de Historia Natural y Antropología, 21(3): 1-24. (in Spanish) ("Preliminary technological considerations about lithic artefacts of Cerro de los Burros (Maldonado, Uruguay)")

Nami, H.G. 2007, Research in the middle Negro River basin (Uruguay) and the Paleoindian occupation of the Southern Cone. Current Anthropology, 48(1): 164-176. doi:10.1086/510465

Nami, H.G. 2009, Crystal quartz and fishtail projectile points: Considerations on raw materials selection by Paleo-South Americans. Current Research in the Pleistocene, 26: 9-12.

Nami, H.G. 2013, Archaelogy, paleoindian research and lithic technology in the Middle Negro River, Central Uruguay. Archaeological Discovery, 1: 1-22. doi:10.4236/ad.2013.11001 
Nami, H.G. in press, Silcrete as a valuable resource for stone tool manufacture and its use by Paleo-American hunter-gatherers in southeastern South America. Journal of Archaeological Science: Reports, 22 p. (Accepted for publication $24^{\text {th }}$ may 2016). doi:10.1016/j.jasrep.2016.05.003

Nami, H.G. \& Castro, A. 2014, Fishtail Points, technology and microwear analysis from the Negro River Basin, Uruguay. Archaeological Discovery, 2: 65-70. doi:10.4236/ad.2014.23008

Nelson, M. C. 1991, The study of technological organization. Archaeological Method and Theory, 3: 57-100. URL: http://www.jstor.org/stable/20170213

Nichols, G. 2009, Sedimentology and stratigraphy ( $2^{\text {nd }}$ ed.). Wiley-Blackwell, Chichester, $419 \mathrm{p}$.

Odell, G. 2000, Stone Tool Research at the End of the Millennium: Procurement and Technology. Journal of Archaeological Research, 8(4): 269-331. doi:10.1023/A:1009439725979

Odell, G. 2004, Lithic Analysis, Manuals in Archaeological Method, Theory, and Technique. Kluwer Academic \& Plenum Publishers, New York, 262 p.

Pellerin, J. 1987, Geología y geomorfología. In: Misión de Rescate Arqueológico, Salto Grande, Vol.1 (Trakalo, R., Ed.), Ministerio de Educación y Cultura, Montevideo: p. 32-54. (in Spanish) (“Geology and geomorphology”)

Penha, U. C. 2015, Prospecção de jazidas líticas em arqueologia: Uma proposta metodológica. Master's thesis, at the Faculdade de Filosofia e Ciências Humanas, Universidade Federal de Minas Gerais, Belo Horizonte, 227 p. (in Portuguese) ("Lithic outcrop survey in archaeology: A methodological proposal")

Pi Hugarte, R. 1993, Los indios de Uruguay. Mapfre, Madrid, 296 p. (in Spanish) ("The Indians of Uruguay")

Piñeiro, G. 2010, Contexto geológico de algunos grabados en piedra. Departamento de Salto, Uruguay. Anuario de Arqueología del Uruguay, 2010: 75-87. (in Spanish) (“Geological context of some petroglyphs. Salto Department, Uruguay”)

Politis, G. 2008, The Pampas and Campos of South America. In: Handbook of South American archaeology (Silverman, H. \& Isbell, W. H., Eds.), Springer, New York: p. 235-260.

Prates, L., Politis, G. \& Steele, J. 2013, Radiocarbon chronology of the early human occupation of Argentina. Quaternary International, 301: 104-122. doi:10.1016/j.quaint.2013.03.011

Rodríguez Saccone, O. 1973, Comunicación preliminar acerca de una industria basáltica en el Río Negro Medio (Dpto. de Durazno). In: Anales del Primer Congreso Nacional de Arqueología y Segundo Encuentro de Arqueología del Litoral (Centro de Estudios Arqueológicos, Ed.), Centro de Estudios Arqueológicos, Montevideo: p. 1-12. (in Spanish) ("Preliminary communication on a basaltic industry in the Middle Negro River (Durazno Department)")

Schiffer, M.B. 1972, Archaeological Context and Systemic Context. American Antiquity, 37(2): 156-165. URL: http://www.jstor.org/stable/278203

Sierra y Sierra, B. 1931, Antropolitos y zoolitos indígenas. Revista de la Sociedad Amigos de la Arqueología, 5: 91-128. (in Spanish) ("Indigenous antropoliths and zooliths") 
Sollazo, F. \& Seijo, C. 1932, A propósito de una punta de lanza. Revista de la Sociedad Amigos de la Arqueología, 6: 335-341. (in Spanish) ("On a spear point”)

Suárez, R. 1999, Cazadores-recolectores en la transición Pleistoceno-Holoceno del norte uruguayo: Fuentes de abastecimiento de materias primas y tecnología lítica. In: Primeras Jornadas del Cenozoico en Uruguay, INGEPA-UNCIEP, Facultad de Ciencias, Montevideo: p. 27-28. (in Spanish) ("Hunter-gatherers of the Pleistocene-Holocene transition from northern Uruguay: Raw material procurement sources and lithic technology")

Suárez, R. 2003, Paleoindian Components of Northern Uruguay: New data for Early Human Occupations of the Late Pleistocene and Early Holocene. In: Where the South Winds Blow: Ancient Evidences from Paleo South Americans (Miotti, L., Salemme, M. \& Flegenheimer, N., Eds.), Center for the Study of the First Americans \& Texas A \& M University Press, College Station: p. 29-36.

Suárez, R. 2004, Arqueología de los Primeros Americanos en Uruguay: Componentes Paleoindios de los Ríos Uruguay-Cuareim y asociación entre cazadores humanos y fauna pleistocénica en el sitio Pay Paso 1. In: X Congreso Uruguayo de Arqueología: La Arqueología Uruguaya ante los desafíos del nuevo siglo (Beovide, L., Barreto, I., \& Curbelo, C., Eds.), Asociación Uruguaya de Arqueología, Montevideo: p. 1-41 (in Spanish) ("Archaeology of the First Americans in Uruguay: Paleoindian components at the Uruguay-Cuareim Rivers and the association between human hunters and Pleistocene fauna at the Pay Paso 1 site")

Suárez, R. 2009, Unifacial Fishtail Points: Considerations about the archaeological record of Paleo South Americans. Current Research in the Pleistocene, 26: 12-15.

Suárez, R. 2010, Arqueología prehistórica en la localidad Arroyo Catalán Chico. Investigaciones pasadas, replanteo y avances recientes. Comisión Sectorial de Investigación Científica, Universidad de la República, Montevideo, 74 p. (in Spanish) ("Prehistoric archaeology at the Catalán Chico River locality. Past research, revision and recent advances")

Suárez, R. 2011a, Arqueología durante la Transición Pleistoceno-Holoceno en Uruguay: Componentes Paleoindios, Organización de la Tecnología Lítica y Movilidad de los Primeros Americanos. BAR International Series Vol. 2220, Archaeopress, Oxford, 254 p. (in Spanish) ("Archaeology during Pleistocene-Holocene transition in Uruguay: Paleoindian components, lithic technological organization and mobility of the first Americans")

Suárez, R. 2011b, Movilidad, acceso y uso de ágata traslúcida por los cazadores-recolectores tempranos durante la transición Pleistoceno-Holoceno en el Norte de Uruguay (ca. 11,000-8,500 a.P). Latin American Antiquity, 22(3): 359-383. (in Spanish) ("Mobility, accessibility and use of translucent agate by early hunter-gatherers during the Pleistocene-Holocene transition in northern Uruguay (ca. 11,000-8,500 BP)"). URL: http://www.jstor.org/stable/23072527

Suárez, R. 2014, Pre-Fishtail settlement in the Southern Cone ca. 15,000-13,100 yr cal BP: Synthesis, evaluation and discussion of the evidence. In: Pre-Clovis in the Americas. International Science Conference Proceedings (Standford, D. J. \& Stenger, A. T., Eds.), The Smithsonian Institution, Middletown: p. 153-191.

Suárez, R. 2015, The Paleoamerican Occupation of the Plains of Uruguay: Technology, Adaptations, and Mobility. PaleoAmerica, 1(1): 88-104. doi:10.1179/2055556314Z.00000000010 
Suárez, R. in press, The human colonization of the southeast of South America: Climatic conditions, technological innovations and the peopling of Uruguay and south of Brazil. Quaternary International, 13 p. (Accepted for publication $21^{\text {st }}$ may 2016). doi:10.1016/j.quaint.2016.02.018

Suárez, R. \& Gillam, J. C. 2008, The Paleoindian database of Uruguay: Collections survey and GIS data development. Current Research in the Pleistocene, 25: 200-202.

Suárez, R. \& Piñeiro, G. 2002, La cantera taller del arroyo Catalán Chico: Nuevos aportes a un viejo problema de la arqueología uruguaya. In: Del mar a los salitrales. Diez mil años de historia pampeana en el umbral del Tercer Milenio (Mazzanti, D.L., Berón, M.A., \& Oliva, F.W., Eds.), Universidad Nacional de Mar del Plata-Sociedad Argentina de Antropología, Mar del Plata: p. 263-279. (in Spanish) ("The Catalán Chico River quarry-workshop: New perspectives on an old problem of Uruguayan archaeology")

Taddei, A. 1964, Un yacimiento precerámico en el Uruguay. Baessler-Archiv, Neue Folge, 12: 317-372. (in Spanish) (“A pre-ceramic site in Uruguay”)

Taddei, A. 1980a, Industrias líticas del Uruguay y su relación con Pampa-Patagonia de Argentina. Primera Parte. Revista de Arqueología, 19(3): 59-64. (in Spanish) ("Lithic industries from Uruguay and their relationship with Argentinean Pampa-Patagonia. Part one")

Taddei, A. 1980b, Industrias líticas del Uruguay y su relación con Pampa-Patagonia de Argentina. Segunda Parte. Revista de Arqueología, 21(3): 24-31. (in Spanish) ("Lithic industries from Uruguay and their relationship with Argentinean Pampa-Patagonia. Part two")

Taddei, A. 1987, Algunos aspectos de la arqueología prehistórica del Uruguay. In: Estudios Atacameños. Investigaciones Paleoindias al Sur de la Línea Ecuatorial (Núñez, L. \& Meggers, B., Eds.), Universidad del Norte, San Pedro de Atacama: p. 62-93. (in Spanish) ("Some aspects of prehistoric archaeology in Uruguay")

Taddei, A., \& Fernández, J.C. 1982, Un precerámico de lascas en el Arroyo Catalán Chico (Dpto. de Artigas). El sitio arqueológico 19-S-4. In: VII Congreso Nacional de Arqueología, Centro de Estudios Arqueológicos (CEA), Montevideo: p. 136-145. (in Spanish) ("A pre-ceramic flake industry in Catalán Chico River (Artigas Department). The archaeological site 19-S-4")

Tuya de Maeso, L. 1977, Prólogo. In: Investigaciones arqueológicas (Tuya de Maeso, L., Ed.), Imprenta Don Bosco, Montevideo: p. 5-8. (in Spanish) ("Prologue")

Vega, J. J. \& R. V. Andrade 2004, “Infierno”: Resultados del análisis realizado sobre el material lítico recuperado en el sitio "Pingüino", Departamento de Río Negro, República Oriental del Uruguay. In: X Congreso Uruguayo de Arqueología: La Arqueología Uruguaya ante los desafíos del nuevo siglo (Beovide, L., Barreto, I., \& Curbelo, C., Eds.), Asociación Uruguaya de Arqueología, Montevideo: p. 1-19. (in Spanish) ("Infierno": Results of lithic analysis of the "Pingüino" site, Río Negro Department, Uruguay") 